\title{
Notch Signaling Augments BMP9- Induced Bone Formation by Promoting the Osteogenesis-Angiogenesis Coupling Process in Mesenchymal Stem Cells (MSCs)
}

\author{
Junyi Liao $o^{\mathrm{a}, \mathrm{b}}$ Qiang Weib,c Yulong Zou ${ }^{\mathrm{b}, \mathrm{c}}$ Jiaming Fan ${ }^{\mathrm{b}, \mathrm{c}}$ Dongzhe Song ${ }^{\mathrm{b}, \mathrm{d}}$

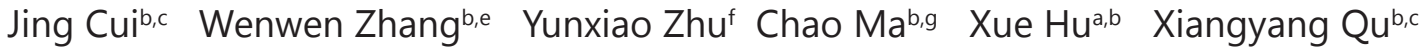 \\ Liqun Chen ${ }^{a, b}$ Xinyi Yu,b Zhicai Zhang ${ }^{b, f}$ Claire Wang ${ }^{b}$ Chen Zhao ${ }^{a, b}$ \\ Zongyue Zeng ${ }^{\mathrm{b}, \mathrm{c}}$ Ruyi Zhang ${ }^{\mathrm{b}, \mathrm{c}}$ Shujuan Yan ${ }^{\mathrm{b}, \mathrm{c}}$ Tingting Wu $\mathrm{u}^{\mathrm{b}, \mathrm{g}}$ Xingye Wu $\mathrm{u}^{\mathrm{a}, \mathrm{b}}$ \\ Yi Shub,c Jiayan Lei ${ }^{a, b}$ Yasha Lib,c Hue H. Luu ${ }^{b}$ Michael J. Lee ${ }^{b}$ Russell R. Reid ${ }^{b, i}$ \\ Guillermo A. Ameer fij Jennifer Moriatis Wolf ${ }^{b}$ Tong-Chuan He $e^{b, c}$ Wei Huang ${ }^{a}$ \\ aDepartments of Orthopaedic Surgery, Blood Transfusion, Nephrology, and General Surgery, The \\ First Affiliated Hospital of Chongqing Medical University, Chongqing, China; ${ }^{b}$ Molecular Oncology \\ Laboratory, Department of Orthopaedic Surgery and Rehabilitation Medicine, The University \\ of Chicago Medical Center, Chicago, USA; 'Ministry of Education Key Laboratory of Diagnostic \\ Medicine, and the Affiliated Hospitals of Chongqing Medical University, Chongqing, 'State Key \\ Laboratory of Oral Diseases, National Clinical Research Center for Oral Diseases, West China Hospital \\ of Stomatology, Sichuan University, Chengdu, eDepartment of Laboratory Medicine and Clinical \\ Diagnostics, the Affiliated Yantai Hospital, Binzhou Medical University, Yantai, China; ${ }^{\mathrm{f} B i o m e d i c a l}$ \\ Engineering Department, Northwestern University, Evanston, USA; ${ }^{9}$ Departments of Neurosurgery and \\ Otolaryngology-Head \& Neck Surgery, the Affiliated Zhongnan Hospital of Wuhan University, Wuhan, \\ hDepartment of Orthopaedic Surgery, Union Hospital of Tongji Medical College, Huazhong University \\ of Science \& Technology, Wuhan, China; 'Department of Surgery, Section of Plastic Surgery, The \\ University of Chicago Medical Center, Chicago, jDepartment of Surgery, Feinberg School of Medicine, \\ Chicago, USA
}

\section{Key Words}

BMP9 signaling • Notch signaling • Osteogenesis-angiogenesis coupling • Mesenchymal stem cells $•$ Bone repair • Regenerative medicine

\footnotetext{
Abstract

Background/Aims: Mesenchymal stem cells (MSCs) are multipotent progenitors that can differentiate into several lineages including bone. Successful bone formation requires osteogenesis and angiogenesis coupling of MSCs. Here, we investigate if simultaneous activation of BMP9 and Notch signaling yields effective osteogenesis-angiogenesis coupling in MSCs. Methods: Recently-characterized immortalized mouse adipose-derived progenitors (iMADs) were used as MSC source. Transgenes BMP9, NICD and dnNotch1 were expressed by adenoviral vectors. Gene expression was determined by qPCR and immunohistochemistry. Osteogenic activity was assessed by in vitro assays and in vivo ectopic bone formation model.

T.-C. He, MD, PhD and Wei Huang, MD, PhD Molecular Oncology Laboratory, The University of Chicago Medical Center, 5841 South Maryland Avenue, MC 3079, Chicago, IL 60637, (USA); Department of Orthopaedic Surgery, The First Affiliated Hospital of Chongqing Medical University, Chongqing 


\section{Cellular Physiology Cell Physiol Biochem 2017;41:1905-1923 and Biochemistry Published online: April 04, $2017 \quad \begin{aligned} & \text { Do 2017 The Authors. } \\ & \text { www.karger.com/cpb }\end{aligned}$ \\ Liao et al.: Coupled Osteoangiogenic Activity by BMP9 and Notch Crosstalk}

Results: BMP9 upregulated expression of Notch receptors and ligands in iMADs. Constitutivelyactive form of Notch1 NICD1 enhanced BMP9-induced osteogenic differentiation both in vitro and in vivo, which was effectively inhibited by dominant-negative form of Notch1 dnNotch1. BMP9- and NICD1-transduced MSCs implanted with a biocompatible scaffold yielded highly mature bone with extensive vascularization. NICD1 enhanced BMP9-induced expression of key angiogenic regulators in iMADs and Vegfa in ectopic bone, which was blunted by dnNotch1. Conclusion: Notch signaling may play an important role in BMP9-induced osteogenesis and angiogenesis. It's conceivable that simultaneous activation of the BMP9 and Notch pathways should efficiently couple osteogenesis and angiogenesis of MSCs for successful bone tissue engineering.

\section{Introduction}

Large bone defects and/or nonunion caused by trauma, metastatic cancers, chronic osteomyelitis and degenerative diseases often pose a significant global health burden [13]. Most surgical interventions involve the use of autograft, which causes significant donor site morbidity, and is limited in availability. The use of alternative allograft for repairing extensive bone defects is also limited by the possibility of infection and host immunological reactions [2]. Thus, effective bone tissue engineering using stem cells, osteoinductive factors and biocompatible scaffold materials holds great promise in the treatment of extensive bone defects $[1,3-6]$.

While several signaling pathways play important roles in regulating osteogenesis [716], bone morphogenetic proteins (BMPs) are considered as a group of the most potent osteoinductive factors [8, 17-19]. We previously demonstrated that BMP9 (also known as growth differentiation factor 2, or GDF2) is one of the most potent BMPs among the 14 types of BMPs in inducing osteogenic differentiation [20-23], partially attributable to the fact that BMP9 is more resistant to noggin inhibition [24]. Mechanistically, BMP9 has been shown to effectively induce osteogenic differentiation of mesenchymal stem cells (MSCs) by regulating a panel of important downstream targets [25-29], as well as through cross-talk with other important signaling pathways [30-35]. Thus, using BMP9-expressing progenitor cells may promote bone regeneration in large bony defects and/or fracture nonunion in clinical settings $[1,22,23]$.

Effective bone formation requires a well-coordinated coupling of osteogenesis and angiogenesis in a 3-D microenvironment [2, 36-39]. In fact, a close spatial-temporal association exists between the processes of angiogenesis and osteogenesis during skeletal development and postnatal bone growth, as well as during healing of bone fractures [38]. We recently demonstrated that BMP9-regulated angiogenic signaling plays an important role in BMP9 or BMP2-induced bone formation [33, 40], and found that BMP9 induces the formation of better vascularized and more mature bone in the presence of scaffold materials [41-43]. It was reported that endothelial Notch signaling promotes osteogenesis and angiogenesis in bone $[37,44]$, while Notch signaling is well recognized as an important regulator of bone formation [45, 46]. Mammals have four Notch receptors (Notch1-4) and five Notch ligands (Delta 1, 3, 4 and Jagged1, and Jagged2) [45, 46]. Notch signaling is activated by ligand binding to Notch receptor, sequential proteolytic cleavages of Notch extracellular domain, and releasing the Notch intracellular domain (NICD) [45-47]. NICD is the functional portion of Notch signaling and interacts with DNA-binding protein CSL (CBF1/Suppressor of Hairless/LAG-1) and regulates downstream genes [46, 47]. We previously showed that BMP9 up-regulates Notch target Hey1 in MSCs [28], and that a blockade of Notch signaling blunts BMP9-promoted tumor growth in osteogenic defective human osteosarcoma cells [48], suggesting an important role of Notch signaling in BMP9-induced osteogenesis.

Here, we used the recently-characterized reversibly immortalized mouse adiposederived MSC cells (iMADs) [43] and demonstrate that BMP9 upregulates the expression of Notch receptors and ligands at the intermediate stage of osteogenic differentiation. The 


\section{Cellular Physiology Cell Physiol Biochem 2017;41:1905-1923 and Biochemistry Published online: April 04, $2017 \quad$\begin{tabular}{l|l} 
Do 2017 The Autho/ \\
www.karger.com/cp
\end{tabular} \\ Liao et al.: Coupled Osteoangiogenic Activity by BMP9 and Notch Crosstalk}

use of the constitutively active form of Notch1 (NICD1) remarkably enhanced BMP9induced osteogenic differentiation both in vitro and in vivo, which was significantly blunted by a dominant-negative Notch1 (dnNotch1). The use of biodegradable citrate-based thermoresponsive PPCNg scaffold [42, 43, 49] led to forming more mature bone with extensive angiogenesis and vascularization when MSCs were stimulated by both BMP9 and NICD1. BMP9 and NICD1 up-regulated the expression of angiogenic regulators in iMAD cells in vtro and Vegfa in ectopic bone tissues. Thus, these results demonstrate that the simultaneous activation of BMP9 and Notch signaling pathways efficiently couples osteogenesis and angiogenesis of MSCs in 3D scaffold environment, which may be ideal for successful bone tissue engineering.

\section{Materials and Methods}

\section{Cell culture and chemicals}

The immortalized mouse adipose-derived multipotent (iMAD) cells are mouse mesenchymal stem cells as previously described [43]. 293pTP cells were derived from HEK-293 cells and overexpression of human Ad5 pTP gene as previously characterized [50]. The cell lines are maintained in Dulbecco's Modified Eagle Medium (DMEM) supplemented with 10\% fetal bovine serum (FBS, Gemini Bio-Products, West Sacramento, CA), containing $100 \mathrm{U} / \mathrm{ml}$ penicillin and $100 \mathrm{mg} / \mathrm{ml}$ streptomycin, at $37^{\circ} \mathrm{C}$ in $5 \% \mathrm{CO}_{2}$ as described [51-53]. Unless indicated otherwise, all other reagents were purchased from Sigma-Aldrich (St. Louis, MO) or Thermo-Fisher Scientific (Waltham, MA).

Construction and generation of recombinant adenoviral vectors Ad-NICD1, Ad-dnNotch1, and AdBMP9

Recombinant adenoviruses were generated by using the AdEasy technology as described [54, 55]. The AdBMP9 and Ad-dnNotch1 were previously characterized [20, 48, 56, 57]. Briefly, the coding regions of human BMP9, the intracellular domain (NICD1) of human NOTCH1, and the extracellular domain with the transmembrane region (aa \#1-aa \#1705) of mouse Notch1 were PCR amplified and subcloned into an adenoviral shuttle vector, and used to generate recombinant adenoviral vectors, resulting in pAd5BMP9, pAd5-NICD1 and pAd-dnNotch1, which were subsequently used to generate recombinant adenoviruses in HEK-293 or 293pTP cells. AdBMP9 also co-expresses enhanced GFP (eGFP), while Ad-NICD1 and AddnNotch1 co-express monomeric RFP (mRFP). AdGFP was used as a mock virus control [30, 35, 58]. For all adenoviral infections, polybrene $(4-8 \mu \mathrm{g} / \mathrm{ml})$ was added to potentiate infection efficiency as previously described [59]. Detailed information about vector construction is available upon request.

Synthesis of polyethylene glycol citrate-co-N-isopropylacrylamide (PPCN)

PPCN was synthesized by the polycondensation of citric acid, glycerol 1,3-diglycerolate diacrylate, poly (ethylene glycol) (PEG) to form an acrylated pre-polymer, which was then reacted with poly-Nisopropylacrylamide as described [49]. The chemical, biodegradable and thermoresponsive features were characterized for each newly synthesized batch as reported [49]. Prior to mixing with cells, PPCN powder was dissolved in PBS (100 mg/ml stock solution), sterilized by syringe filtration using $0.22 \mu \mathrm{m}$ filters, and kept at $4^{\circ} \mathrm{C}$. To prepare the scaffold for cell entrapment, gelatin was added to PPCN to obtain a final concentration of $0.1 \%(\mathrm{w} / \mathrm{v})$ gelatin in the PPCN solution and corresponding hydrogel scaffold, referred to as PPCNg.

RNA isolation and touchdown quantitative PCR (TqPCR)

At 3, 5, 7, and/or 9 days after adenovirus infection, total RNA was isolated by using TRIZOL Reagent (Invitrogen, Carlsbad, CA) according to the manufacturer's instructions and subjected to reverse transcription reactions using hexamer and M-MuLV Reverse Transcriptase (New England Biolabs, Ipswich, MA). The resultant cDNA products were diluted 10- to 100-fold and used as PCR templates. PCR primers were designed by using the Primer3 Plus program [60]. The quantitative PCR analysis was carried out using our recently optimized TqPCR protocol $[61,62]$. Briefly, the SYBR Green qPCR reactions (Bio-Rad Laboratories) were set up according to manufacturer's instructions. The cycling program was modified by incorporating 4 cycles of touchdown steps prior to the regular cycling program. Gapdh was used as a reference gene. All sample values were normalized to Gapdh expression. All qPCR primer sequences are listed in Table 1. 


\section{Cellular Physiology Cell Physiol Biochem 2017;41:1905-1923 \begin{tabular}{l|l} 
DOI: 10.1159/000471945 & $\begin{array}{l}\text { () 2017 The Author(s). Published by S. Karger AG, Basel } \\
\text { www.karger.com/cpb }\end{array}$
\end{tabular} \\ Liao et al.: Coupled Osteoangiogenic Activity by BMP9 and Notch Crosstalk}

The expression of osteogenic regulators Runx2 and Osterix was only assessed in day 3 and day 5 samples, while late osteogenic markers Opn, Ocn, Bsp and Col1a1 were ananlyzed in day 7 and day 9 samples as well.

Alkaline phosphatase (ALP) assay

The ALP activities were assessed using the modified Great Escape SEAP chemiluminescence assay (BD Clontech) and/or histochemical staining as described previously [31, 32, 63, 64]. Early osteogenic marker ALP activity was assessed at 3, 5, and 7 days after adenovirus infection. For the histochemical staining of ALP activity, the cells were fixed with $0.05 \%$ glutaraldehyde at room temperature for 10 minutes. After washing with PBS, cells were subjected to histochemical staining with a mixture of $0.1 \mathrm{mg} / \mathrm{mL}$ of napthol AS-MX phosphate and $0.6 \mathrm{mg} / \mathrm{mL}$ of Fast Blue BB salt. Histochemical staining was recorded using bright light microscopy. For chemiluminescence assay, cells were lysed by cell culture lysis reagent (Promega, USA), and then $5 \mu \mathrm{l}$ cell lysis, 5 ul substrate (BD Clontech) and $15 \mu \mathrm{l}$ Lupo buffer were mixed well, followed by protected from light at room temperature for 20 minutes. Each assay condition was performed in triplicate, and the results were repeated in at least three independent experiments. ALP activity was normalized by total cellular protein concentrations among the samples.

\section{Matrix mineralization assay (Alizarin Red S staining)}

The iMAD cells were seeded in 24-well plates and infected with adenoviruses. Infected cells were cultured in the presence of ascorbic acid $(50 \mathrm{mg} / \mathrm{ml})$ and $\beta$-glycerophosphate $(10 \mathrm{mM})$. On day 7 and day 14 after infection, mineralized matrix nodules were stained for calcium precipitation by means of Alizarin Red S staining as described [20,21]. Briefly, cells were fixed with 1\% glutaradehyde for 10 minutes. After being washed with PBS, cells were incubated with $2 \%$ Alizarin Red S at room temperature for 30 minutes, followed by washing with acidic PBS ( $\mathrm{pH}=4.2)$. The staining of calcium mineral deposits was documented under bright field microscopy.

\section{Subcutaneous stem cell implantation and ectopic bone formation}

The use and care of animals in this study were approved by the Institutional Animal Care and Use Committee. All experimental procedures were carried out in accordance with the approved guidelines. The subcutaneous stem cell implantation was performed as described $[21,58,65,66]$. Sterile $0.2 \%(\mathrm{w} / \mathrm{v})$ gelatin was prepared from $2 \%(\mathrm{w} / \mathrm{v}$ ) gelatin solution (Sigma-Aldrich, Cat\# G1393). Sterile PPCN solution was prepared at $100 \mathrm{mg} / \mathrm{ml}$. Briefly, the iMAD cells were infected with different adenoviruses. At $24 \mathrm{~h}$ after infection, cells were collected and either added to PPCNg or used in suspension. For the PPCNg group, the cells were resuspended in PPCNg solution ( $40 \mathrm{ul} \mathrm{PPCN} \mathrm{+40ul} \mathrm{gelatin} \mathrm{for} \mathrm{each} \mathrm{injection} \mathrm{site)} \mathrm{as} \mathrm{described}$ $[42,43]$. For the iMAD cell only group, the cells were resuspended in PBS (80ul each injection). PPCNg with or without iMADs cells was kept on ice and injected subcutaneously into athymic nude mice (Envigo/Harlan Research Laboratories; $n=5$ /group, female, 5-6 week old). $2 \times 10^{6}$ cells per injection site were used for 


\section{Cellular Physiology Cell Physiol Biochem 2017;41:1905-1923

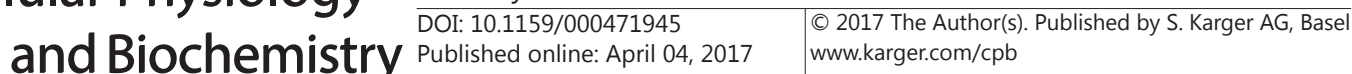 \\ Liao et al.: Coupled Osteoangiogenic Activity by BMP9 and Notch Crosstalk}

all groups. The animals were maintained ad lib in the biosafety barrier facility. At the end of 4 and 6 weeks after implantation, animals were euthanized, and the ectopic masses were retrieved from injection sites and subjected to micro-CT imaging, followed by histological and other evaluations. PPCNg scaffold material was biodegradable and expected to degrade completely after 4-6 weeks in subcutaneous implantation as previously reported $[42,43]$.

\section{Micro-Computed Tomographic $(\mu \mathrm{CT})$ imaging analysis}

The retrieved specimens were fixed in $10 \%(\mathrm{v} / \mathrm{v})$ formalin and imaged with the micro-CT $(\mu \mathrm{CT})$ component of the GE triumph (GE Healthcare) trimodality preclinical imaging system. The $\mu \mathrm{CT}$ system has a tungsten target X-ray tube, which was acquired with an X-ray source of $60 \mathrm{kVp}$ and $140 \mu \mathrm{A}$. A single frame of 512 projections of continuous X-ray exposure was used for CT acquisitions. Volumetric CT images were reconstructed in a $512 \times 512 \times 512$ format with voxel dimensions of $115 \mu \mathrm{m}^{3}$. All image data analyses were performed using Amira 5.3 (Visage Imaging, Inc.), and 3D volumetric data were determined as previously described $[67,68]$.

\section{Hematoxylin and Eosin (H\&E) and Masson's Trichrome staining}

The retrieved specimens were fixed with $10 \%$ formalin, decalcified and embedded in paraffin. Serial sections at $5 \mu \mathrm{m}$ of embedded specimens were carried out, and mounted onto treated slides. The sections were deparaffinized and then rehydrated in a graduated fashion. H\&E staining and Masson's Trichrome staining were done as described $[35,69,70]$.

\section{Immunohistochemical staining}

Immunohistochemical staining was done as previously described [71-73]. Briefly, the sections were deparaffinized and rehydrated in a graduated fashion, and then subjected to antigen retrieval. After being washed with PBS, the sections were blocked with 5\% donkey serum and then incubated with the VEGF $\alpha$ antibody (Santa Cruz Biotechnology, sc-7269, 1:100 dilution) at $4^{\circ} \mathrm{C}$ overnight. After being washed, sections were incubated with biotin-labeled secondary antibody for 30 minutes, followed by incubating cells with streptavidin-HRP conjugate for 20 minutes at room temperature. The presence of the protein of interest was visualized by DAB staining and examined under a microscope. Staining without the primary antibody was used as a negative control.

\section{Statistical analysis}

All quantitative experiments were performed in triplicate and/or repeated three times. Data were expressed as mean \pm standard deviation (SD). The one-way analysis of variance was used to analyze statistical significance. A value of $p<0.05$ was considered statistically significant.

\section{Results}

$B M P 9$ up-regulates the expression of notch receptors and ligands at an intermediate stage of BMP9-induced osteogenic differentiation of MSCs

To determine whether BMP9 exerted any effect on Notch signaling, we examined the expression of Notch receptors and ligands upon BMP9 stimulation in MSCs. When the iMADs were transduced with AdBMP9, we found that the expression of Notch1, Notch3 and Notch4 was significantly upregulated at day 5 , but not at day 3 (Fig. 1A). Similarly, the expression of Notch ligands Dll1, Dll3 and Dll4 was elevated at day 5, while the expression of Jagged1 and, to a lesser extent, Jag2 was up-regulated at both day 3 and day 5 (Fig. 1B). These results strongly suggest that, compared to the induction of early response genes such as Id1, Id2 and Id3 [25, 26], Notch receptors and ligands may be up-regulated at an intermediate stage, although not immediate early stage, of the BMP9-induced osteogenic differentiation.

Activation of Notch signaling by the Notch1 intracellular domain (NICD1) enhances BMP9-induced osteogenic differentiation

To effectively and specifically activate the Notch signaling pathway, we constructed an adenoviral vector expressing the active form of Notch1, the Notch1 intracellular domain (NICD1) [48]. We showed that the viral vector AdNICD1 was able to infect the iMAD 


\section{Cellular Physiology and Biochemistry}

Cell Physiol Biochem 2017;41:1905-1923

\begin{tabular}{l|l}
\hline DOI: $10.1159 / 000471945$ & (c) 2017 The Author(s). Published by S. Karger AG, Base
\end{tabular}

Published onlıne: April 04, 2017 www.karger.com/cpb

Liao et al.: Coupled Osteoangiogenic Activity by BMP9 and Notch Crosstalk
Fig. 1. BMP9 up-regulates the expression of Notch receptors and ligands at the intermediate stage of osteogenic differentiation of MSCs. Exponentially growing iMADs were infected with AdBMP9 or AdGFP. At the indicated time points, total RNA was isolated and subjected to TqPCR analysis using PCR primers specific for mouse Notch receptors (A) and Notch ligands (B). All samples were normalized with the reference gene Gapdh. Each assay condition was done in triplicate. Relative expression was calculated by dividing the relative expression values (i.e., gene/Gapdh) in BMP9-treated group with that from the GFP-treated group. “**” $\mathrm{p}<0.001$, “*” $\mathrm{p}<$ 0.05, AdBMP9 group vs. AdGFP group.

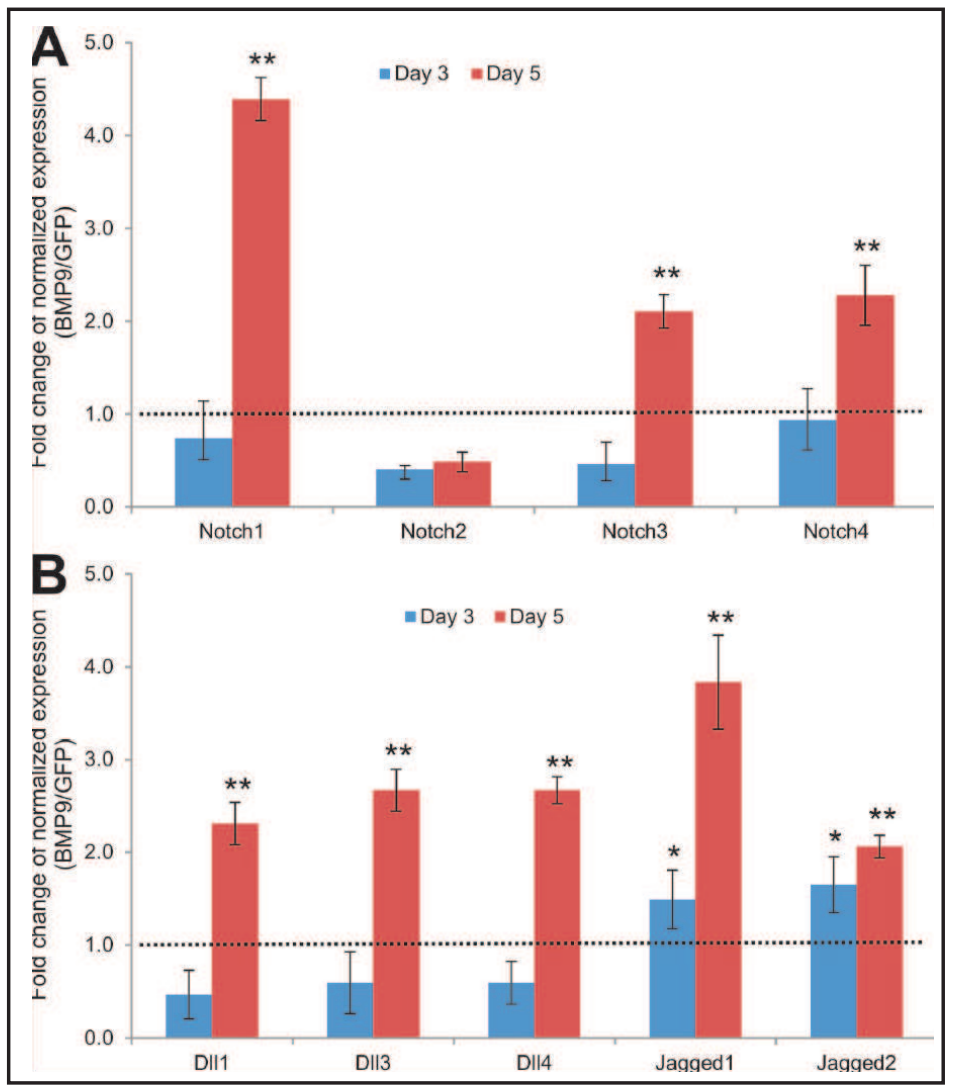

cells effectively and was well suited for co-infection with AdBMP9 (Fig. 2A, panel a). The adenoviral vector-mediated NICD1 transgene expression was readily detected and lasted at least up to 7 days (Fig. 2A, panel b). Functionally, AdNICD1 was shown to effectively induce the expression of known Notch target genes Hey1 and Hey2 (Fig. 2A, panels c \& d). These results demonstrate that AdNICD1 can effectively activate the downstream events of Notch signaling.

When iMAD cells were co-transduced with AdBMP9 or AdGFP and/or AdNICD1, we found that the BMP9-induced early osteogenic marker alkaline phosphatase (ALP) activity was significantly enhanced by AdNICD1 at as early as day 3 in histochemical staining, with continued increases at day 5 and day 7 (Fig. 2B, panel a). Quantitatively, the BMP9-induced ALP activity was shown to be enhanced by the co-expression of NICD1 in iMADs cells (Fig. $2 \mathrm{~B}$, panel b). Furthermore, the BMP9-induced in vitro matrix mineralization was markedly enhanced by co-expression of NICD1 at as early as day 7 and continued to increase at day 14 (Fig. 2C, panels a \& b).

We further analyzed the effect of Notch signaling on the expression of osteogenic regulators and bone markers. We found that BMP9-induced expression of Runx 2 and Osterix was significantly enhanced by NICD1 co-expression at day 3 (Fig. 3 a \& b), coinciding with the onset of effective osteogenic differentiation of iMAD cells. Furthermore, the BMP9-induced expression of late bone markers Opn, Ocn, Bsp, and Col1a1 was further up-regulated by NICD1 co-expression at day 5 and/or later (Fig. 3 c to f). Taken together, these results demonstrate that the activation of Notch signaling by overexpression of NICD1 may significantly enhance BMP9-induced osteogenic differentiation of MSCs.

\section{A dominant-negative Notch1 (dnNotch1) diminishes BMP9-induced osteogenic differentiation in MSCS}

To effectively and specifically inhibit Notch signaling, we constructed an adenoviral vector expressing a dominant-negative mutant of Notch1, which contains the extracellular and transmembrane region of Notch1. We showed that this Ad-dnNotch1 was able to 


\section{Cellular Physiology Cell Physiol Biochem 2017;41:1905-1923 \begin{tabular}{l|l} 
and Biochemistry Published onlIne: AprIl 04, 2017 & $\begin{array}{l}\text { ( ) 2017 The Author(s). Published by S. Karger AG, Basel } \\
\text { www.karger.com/cpb }\end{array}$
\end{tabular}}

Liao et al.: Coupled Osteoangiogenic Activity by BMP9 and Notch Crosstalk

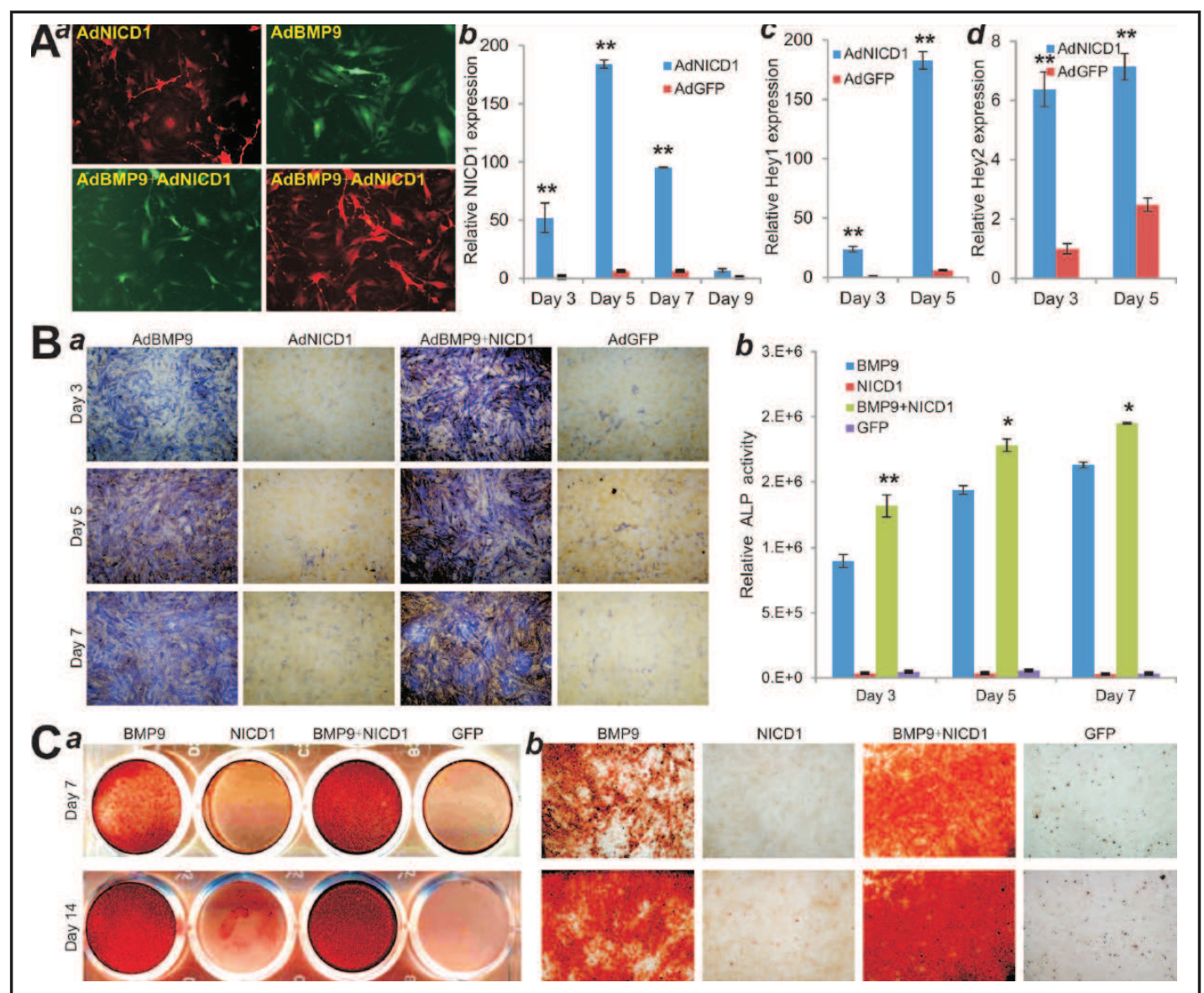

Fig. 2. Activation of Notch signaling by the Notch1 introcellular domain (NICD1) enhances BMP9-induced osteogenic differentiation in vitro. (A) Adenovirus expressing NICD1 can transduce iMAD cells with high efficiency and can co-infect MSCs $(a)$, and the transgene NICD1 is highly expressed $(b)$ and is able to upregulate Notch downstream targets Hey1 and Hey2 in iMADs $(c \& d)$. All samples were normalized with the reference gene Gapdh. Each assay condition was done in triplicate. “**” $\mathrm{p}<0.001$, “*” $\mathrm{p}<0.05$, AdNICD1 group vs. AdGFP group. (B) NICD expression augments BMP9-indueced ALP activity in MSCs. Subconfluent iMADs were infected with AdBMP9 or AdGFP and/or Ad-NICD1. At the indicated time points, the infected cells were subjected to ALP activity assays by either histochemical staining ( $a$ ) or quantitative the bioluminescence assay $(b)$. Each assay conditions were done in triplicate. Representative staining is shown. “**” $\mathrm{p}<$ 0.001, “*” p < 0.05, AdBMP9 group vs. AdBMP9 + Ad-NICD1 group. (C) NICD expression augments BMP9-indueced matrix mineralization in MSCs. Subconfluent iMADs were infected with AdBMP9 or AdGFP and/ or Ad-NICD1, and cultured in mineralization medium. At the indicated time points, the infected cells were fixed and subjected to Alizarin Red S staining. Each assay conditions were done in triplicate. Representative gross images $(a)$ and microscopic images $(b)$ are shown.

effectively inhibit Notch signaling in human osteosarcoma cells previously [48]. We showed that Ad-dnNotch1 alone or with AdBMP9, transduced iMADs effectively (Fig. 4A, panel a). When the iMADs were co-infected with AdBMP9 and Ad-dnNotch1, we found BMP9-induced ALP activity was significantly inhibited at day 3, and to lesser extents at days 5 and 7 (Fig. $4 \mathrm{~A}$, panel b), which was further confirmed by the quantitative ALP assays (Fig. 4A, panel c). Using Alizarin Red staining, we found that BMP9-induced matrix mineralization in the iMAD cells was significantly inhibited by dnNotch1 (Fig. 4B, panels a \& b).

Furthermore, we found that BMP9-induced expression of Runx2 and Osterix was effectively inhibited by dnNotch1 at both day 3 and day 5 ( p < 0.05) (Fig. 5 , panels a \& b). Accordingly, BMP9-induced expression of late bone markers Opn, Ocn, Bsp, and Col1a1 was significantly inhibited by dnNotch1 co-expression ( $\mathrm{p}<0.001$ ) (Fig. 5, panels c to f). Collectively, 


\section{$\begin{array}{ll}\text { Cellular Physiology } & \text { Cell Physiol Biochem 2017;41:1905-1923 } \\ \text { DOI: 10.1159/000471945 } & \text { ( } 2017 \text { The Author(s). Published by S. Karger AG, Basel }\end{array}$

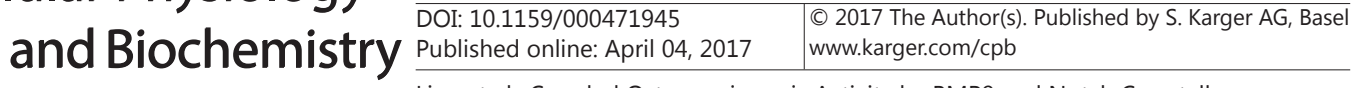

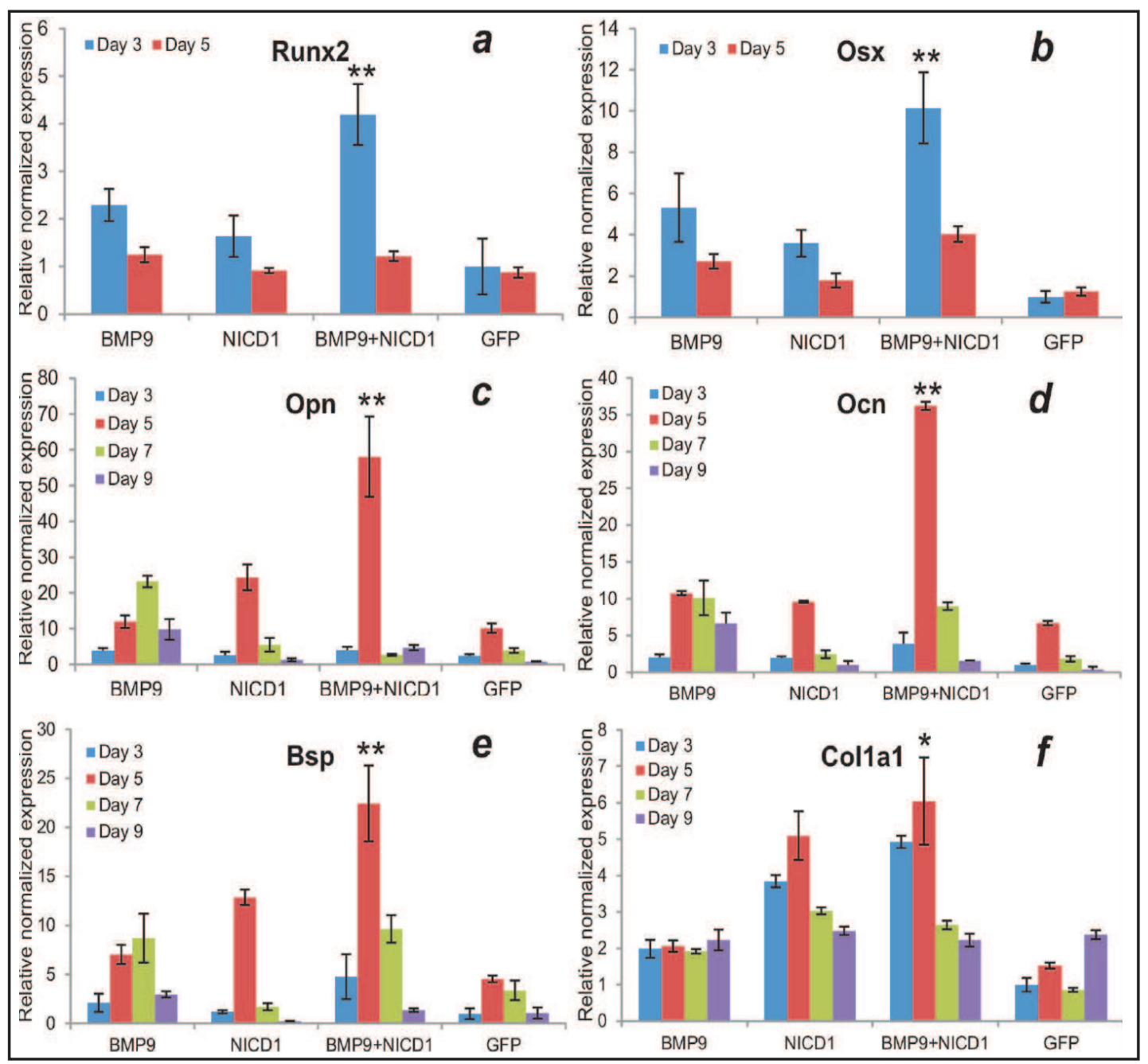

Fig. 3. NICD1 expression enhances BMP9-induced expression of osteogenic regulators and bone markers in MSCs. Subconfluent iMADs were infected with AdBMP9 or AdGFP and/or Ad-NICD1. At the indicated time points, total RNA was isolated and subjected to qPCR analysis using primers for mouse Runx2 $(a)$, Osx $(b)$, Opn $(c), 0 \mathrm{cn}(d)$, Bsp $(e)$, and Col1a1 $(f)$. Each assay condition was done in triplicate. Relative expression was calculated by dividing the relative expression values (i.e., gene/Gapdh) in treatment group with that from the GFP-treated group. “**” $\mathrm{p}<0.001$, “*” $\mathrm{p}<0.05$, AdBMP9 group vs. AdBMP9 + AdNICD1 group.

these results demonstrate that the inhibition of Notch signaling by overexpression of dnNotch1 may significantly attenuate BMP9-induced osteogenic differentiation, which is consistent with the notion that Notch signaling plays an important role in BMP9-induced osteogenic differentiation of MSCs.

Activation of Notch signaling by NICD1 significantly improves the maturity and quality of BMP9-induced ectopic bone formation by increasing angiogenic activity and neovascularization

We conducted ectopic bone formation assays to test the effect of Notch signaling on BMP9-induced osteogenic differentiation in vivo. The iMADs cells were first infected with AdBMP9 or AdGFP and/or AdNICD1 or Ad-dnNotch1 in vitro. The infected iMADs were collected, mixed with or without the thermoresponsive biodegradable material PPCNg [42], and subcutaneously injected into the flanks of athymic nude mice for 4 and 6 weeks. Consistent with our previous report [43], no masses were retrieved from the injection sites in the AdGFP only group, AdNICD1 only group, and Ad-dnNotch1 only group. 


\section{Cellular Physiology Cell Physiol Biochem 2017;41:1905-1923

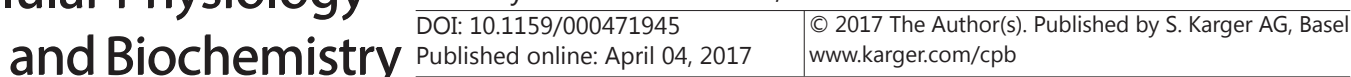

Liao et al.: Coupled Osteoangiogenic Activity by BMP9 and Notch Crosstalk

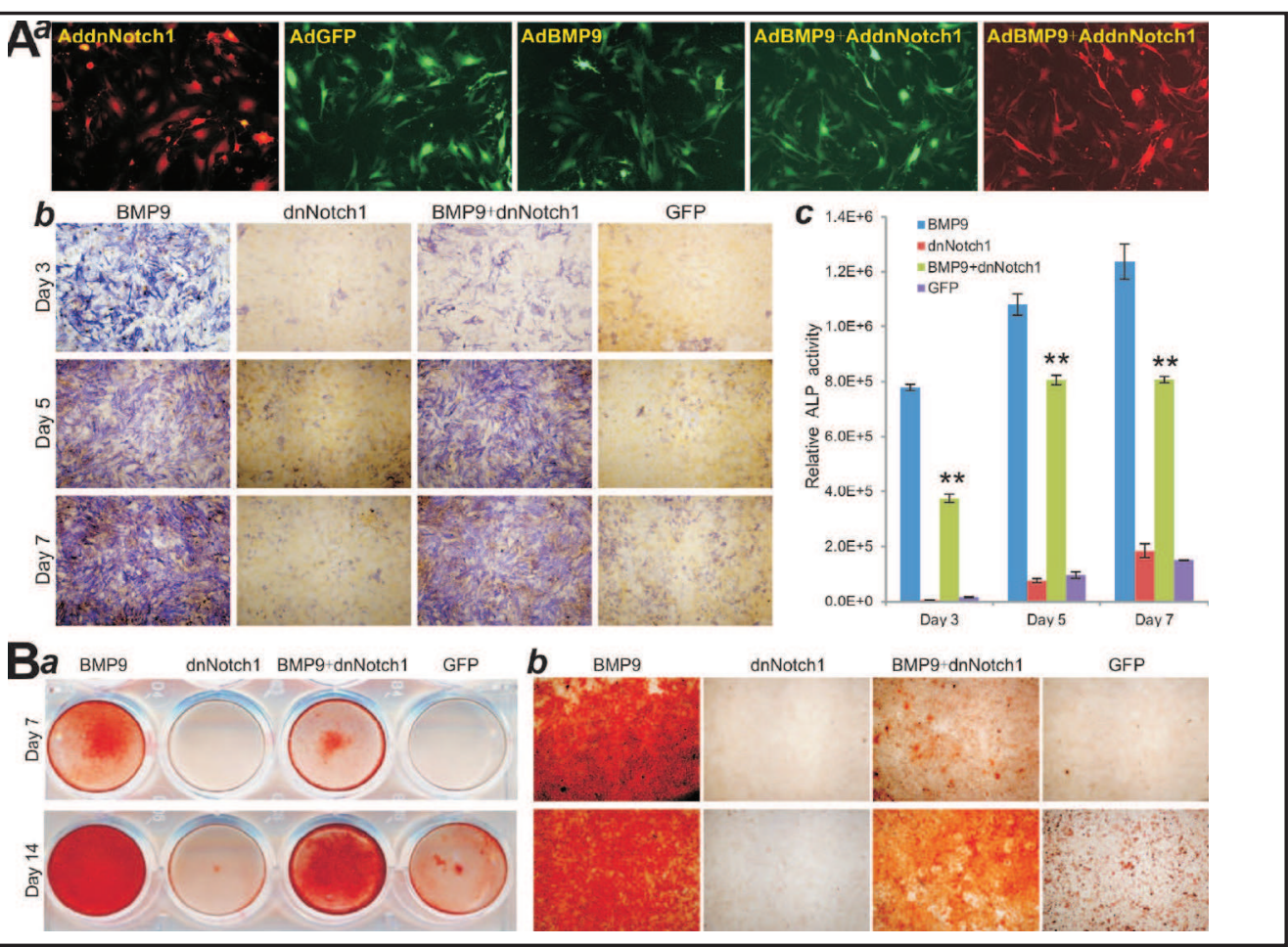

Fig. 4. A dominant-negative Notch1 (dnNotch1) diminishes BMP9-induced osteogenic differentiation in MSCs. (A) Expression of dnNotch1 diminishes BMP9-indueced ALP activity in MSCs. Subconfluent iMADs were infected with AdBMP9 or AdGFP and/or Ad-dnNotch1 (a). At the indicated time points, the infected cells were subjected to ALP activity assays by either histochemical staining (b) or quantitative the bioluminescence assay (c). Each assay conditions were done in triplicate. Representative staining is shown. "**” $\mathrm{p}<$ 0.001, AdBMP9 group vs. AdBMP9 + Ad-dnNotch1group. (B) Expression of dnNotch1 attenuates BMP9-indueced matrix mineralization in MSCs. Subconfluent iMADs were infected with AdBMP9 or AdGFP and/or Ad-dnNotch1 and cultured in mineralization medium. At the indicated time points, the infected cells were fixed and subjected to Alizarin Red S staining. Each assay conditions were done in triplicate. Representative gross (a) and microscopic images (b) are shown.

$\mu \mathrm{CT}$ imaging indicated that all BMP9-treated iMADs groups formed robust bone at week 4 and week 6 (Fig. 6A, panels a \& b). No significant differences in average bone volume were observed among all groups (Fig. 6A, panel c). Nonetheless, when compared with that of the BMP9 only groups, the BMP9+NICD1 groups with or without scaffold materials, consistently exhibited higher mean bone mineral density, whereas the BMP9+dnNotch1 groups had lower mean bone density (Fig. 6A, panel d). Histologic staining shows that the BMP9+NICD1 groups have more robust bone formation, more trabecular structure and better mineralization than that of the BMP9 only groups' (Fig. 6B, panels a \& b). In the presence of PPCNg, NICD1 significantly facilitated the BMP9-induced osteogenic differentiation of iMADs into mature bone matrices with less undifferentiated iMADs left at the center of the masses and inhibited adipogenesis (Fig. 6B). On the contrary, overexpression of dnNotch1 significantly impaired BMP9-induced osteogenic differentiation and bone formation under the same condition, and seemingly promoted adipogenesis, especially in the absence of PPCNg (Fig. 6B panels a \& b). Trichrome staining confirmed that NICD1 expression significantly enhanced the BMP9induced mineralization and bone quality from the iMADs cells, while blockade of Notch signaling by dnNotch1 effectively inhibited BMP9-induced bone formation at both weeks 4 and 6 (Fig. 6C panels a \& b).

Histologic analysis of the retrieved bony samples further revealed that NICD1 overexpression significantly promoted angiogenesis and vascularization in the BMP9-induced, 


\section{Cellular Physiology Cell Physiol Biochem 2017;41:1905-1923 \begin{tabular}{c|l} 
DOI: 10.1159/000471945 & $\begin{array}{l}\text { O } 2017 \text { The Author(s). Published by S. Karger AG, Basel } \\
\text { www.karger.com/cpb }\end{array}$
\end{tabular} \\ Liao et al.: Coupled Osteoangiogenic Activity by BMP9 and Notch Crosstalk}

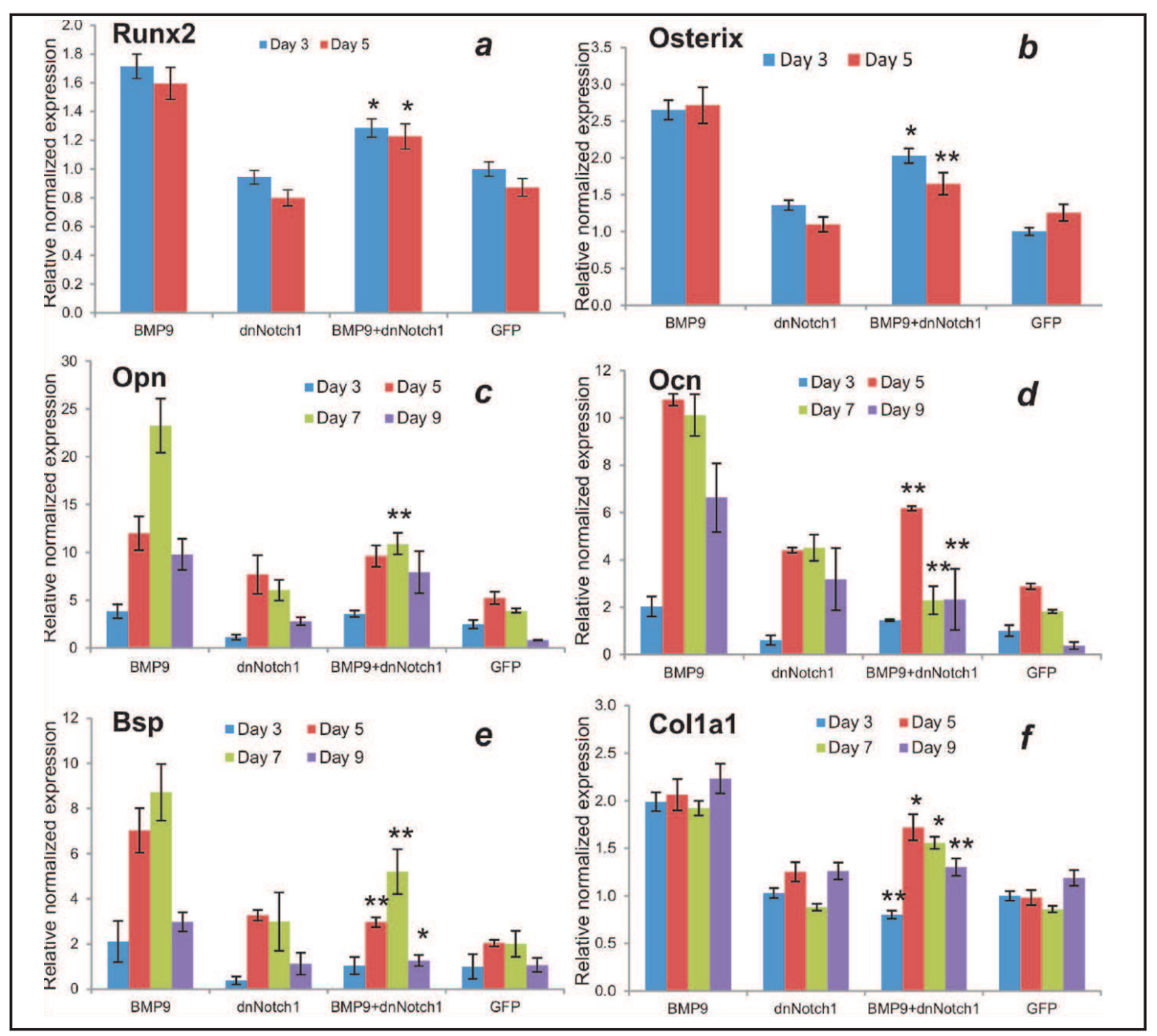

Fig. 5. The dnNotch1attenuates BMP9-induced expression of osteogenic regulators and bone markers in MSCs. Subconfluent iMADs were infected with AdBMP9 or AdGFP and/or Ad-dnNocth1. At the indicated time points, total RNA was isolated and subjected to qPCR analysis using primers for mouse Runx2 (a), Osx (b), Opn (c), Ocn (d), Bsp (e), and Col1a1 (f). Each assay condition was done in triplicate. Relative expression was calculated by dividing the relative expression values (i.e., gene/Gapdh) in treatment group with that from the GFP-treated group. “**” $\mathrm{p}<0.001$, “*” $\mathrm{p}<0.05$, AdBMP9 group vs. AdBMP9 + Ad-dnNotch1 group.

newly formed bone masses at both week 4 and week 6 (data not shown). Quantitatively, the average numbers of blood vessels observed in the BMP9+NICD1 groups, both with and PPCNg, are significantly higher than of the BMP9 only groups (data not shown). Collectively, these in vivo results demonstrate that activation of Notch signaling enhances BMP9-induced ectopic bone formation by increasing angiogenic activity and neovascularization, especially in the presence of the scaffold biomaterial PPCNg.

Activation of Notch signaling enhances BMP9-induced angiogenic activity in MSCs

To explore the potential mechanism underlying NICD1-enhanced angiogenic activity in BMP9-stimulated MSCs, we analyzed the effect of NICD1 and/or BMP9 on the expression of known angiogenic factors such as Vegfo, Angiopoietin 1 (Angpt1) and Angiopoietin 2 (Angpt2). We found that overexpression of NICD1 in the iMADs was able to up-regulate the expression of Vegf $\alpha$ and Angpt2 at both day 3 and day 5, but that of Angpt1 only at day 5 (Fig. $7 \mathrm{~A}$, a \& c vs. b). BMP9 stimulation alone in the iMADs was shown to effectively induce the expression of Vegf $\alpha$, Angpt1 and Angpt2, mostly at day 5 (Fig. 7A), which is consistent with our earlier studies [43]. Overexpression of dnNotch1 alone did not significantly affect the 


\section{Cellular Physiology Cell Physiol Biochem 2017;41:1905-1923 \begin{tabular}{c|l} 
DOI: 10.1159/000471945 & $\begin{array}{l}\text { O } 2017 \text { The Author(s). Published by S. Karger AG, Basel } \\
\text { www.karger.com/cpb }\end{array}$ \\
\hline
\end{tabular}}

Fig. 6. Activation of Notch signaling by NICD1 significantly improves the maturity and quality of BMP9-induced ectopic bone formation, which is inhibited by dnNotch1 in MSCs. (A) MicroCT imaging (3D reconstructions and cross-sectional images) of the retrieved bone masses from different groups with or without PP$\mathrm{CNg}$ scaffold materials at 4 weeks (a) and 6 weeks (b). (B) $\mathrm{H} \& \mathrm{E}$ staining of the retrieved bone masses at week 4 (a) and week 6 (b). The microCT data were quantitatively analyzed to determine the average bone volume (c) and mean bone mineral density (d). “*” $\mathrm{p}<0.05$, “**” $\mathrm{p}<0.001$, compared with that of the respective BMP9 only groups. Trabecular bone is indicated by arrows. (C) Masson's Trichrome staining of the retrieved bone masses at week 4 (a) and week 6 (b). Trabecular bone is indicated by arrows. Representative images are shown.

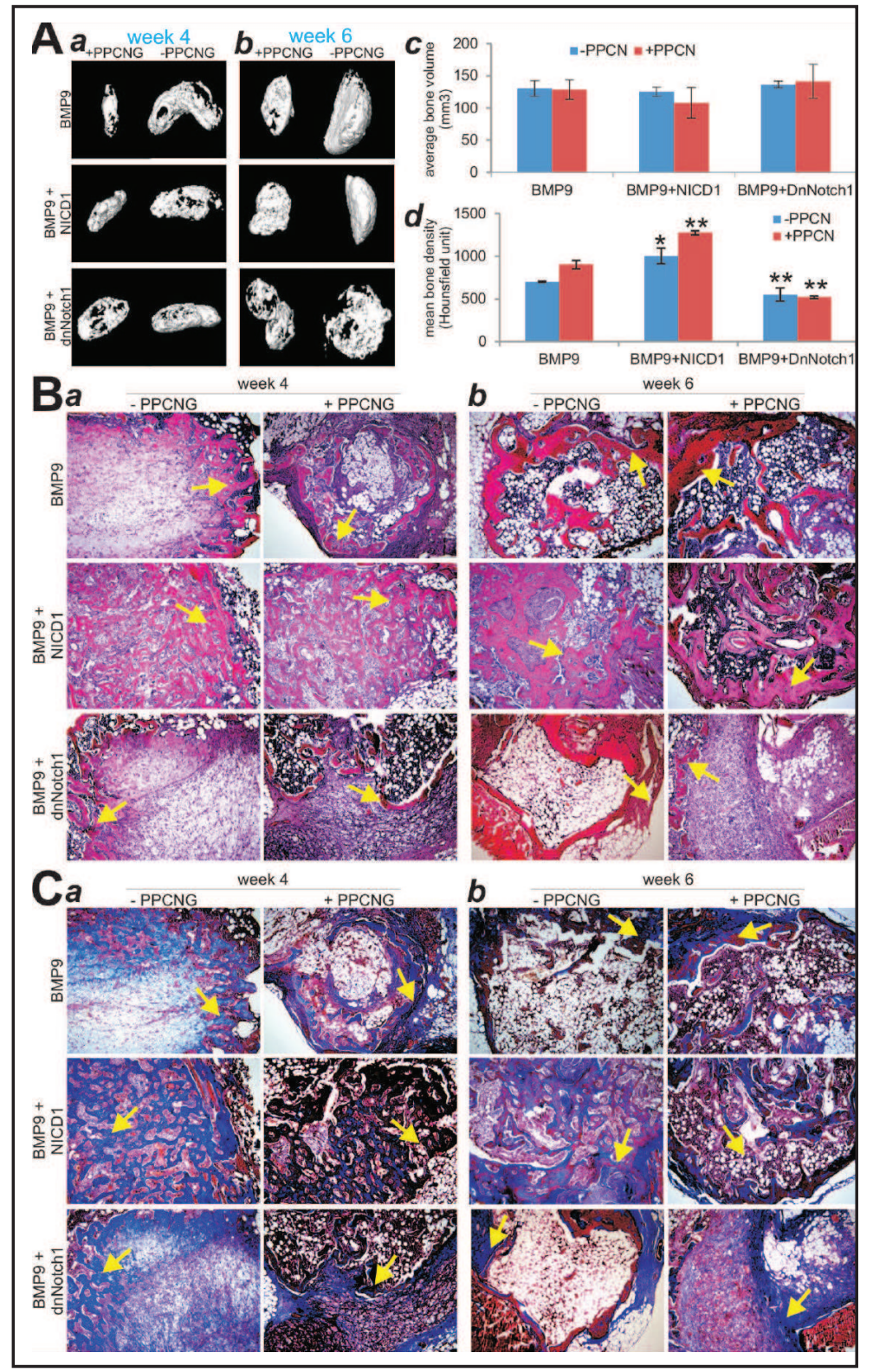

expression of these three genes. However, co-expression of BMP9 and NICD1 in the iMADs led to significant increases in the expression of Vegf $\alpha$, Angpt1 and Angpt2, compared with that of either BMP9 or NICD1 stimulation alone (Fig. 7A). Conversely, overexpression of dnNotch1 was shown to inhibit BMP9-induced the expression of these three genes (Fig. 7A).

We further examined the Vegf $\alpha$ expression in the retrieved bone masses through immunohistochemical staining. We found that, whereas BMP9 treatment led to an increase in the expression of Vegf $\alpha$, co-expression of BMP9 and NICD1 profoundly upregulated Vegf $\alpha$ expression (Fig. 7). Conversely, dnNotch1 was shown to effectively inhibit BMP9upregulated Vegfo expression (Fig. 7). It's noteworthy that the elevation of Vegfo expression in BMP9 alone or BMP9/NICD1 treatment group was more pronounced in the presence of PPCNg (Fig. 7 panels a vs. b), suggesting that scaffold materials may provide a more favorable microenvironment for neovascularization and angiogenesis. Taken together, our findings strongly suggest that activation of Notch signaling may significantly enhance BMP9-induced angiogenic activity in the osteogenic-angiogenic coupling process of bone formation from MSCs. 


\section{Cellular Physiology Cell Physiol Biochem 2017;41:1905-1923 \begin{tabular}{ll|l} 
and Biochemistry Published on/ne: April 04, 2017 & $\begin{array}{l}\text { ○ 2017 The Author(s). Published by S. Karger AG, Basel } \\
\text { www.karger.com/cpb }\end{array}$ \\
\hline
\end{tabular}}

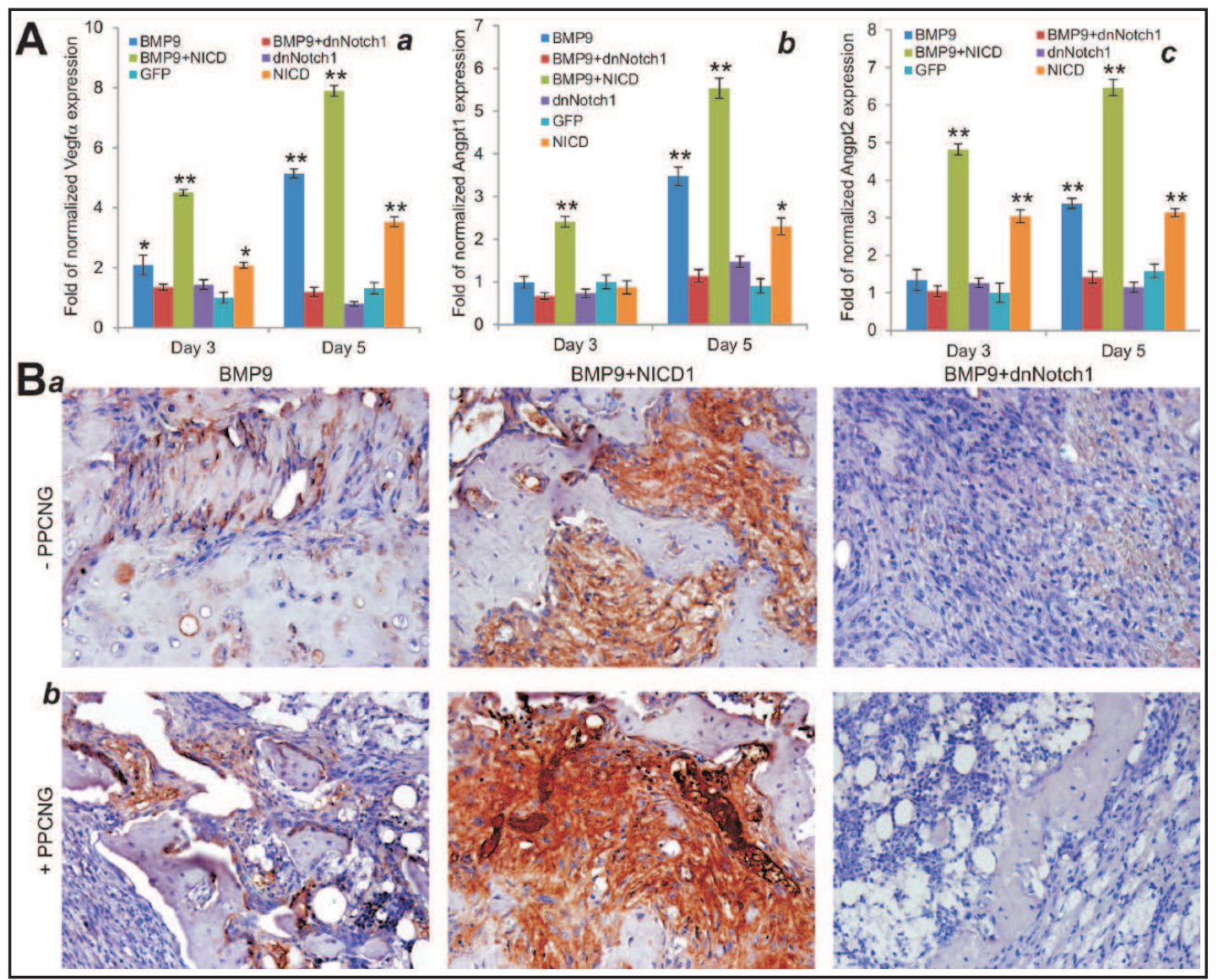

Fig. 7. NICD enhances BMP9-induced angiogenic factors in MSCs and bone tissues, which is blocked by dnNotch1. (A) Effects of NICD and dnNotch1 on BMP9-induced expression of angiogenic factors. Subconfluent iMADs were infected with the indicated combinations of adenoviral vectors. At the indicated time points, total RNA was isolated and subjected to qPCR analysis using primers for mouse Vegf $\alpha$ (a), Angpt1 (b) and Angpt2 (c). Each assay condition was done in triplicate. Relative expression was calculated by dividing the relative expression values (i.e., gene/Gapdh) in treatment group with that from the GFP-treated group. “**” $\mathrm{p}<0.001$, “*” $\mathrm{p}<0.05$, treatment group vs. AdGFP group. (B) Immunohistochemical staining of Vegf $\alpha$ expression in the retrieved ectopic bone masses (week 4). The paraffin-embedded samples were sectioned, deparaffinized and subjected to immunohistochemical staining using the Vegf $\alpha$ antibody (Cat\# sc-7269, 1:100 dilution, Santa Cruz Biotechnology). Species-specific IgG and minus primary antibody were used as negative controls (not shown). Representative images are shown.

\section{Discussion}

Limited vascularization may seriously affect the overall success of the engineered bone and bone grafts. Clinically, the lack of vascularity results in poor integration between bone grafts and host bone and is the main cause for the failure of bone autografts or allografts $[2,3]$. Thus, promoting vascularization by optimizing effective osteogenesis-angiogenesis coupling is essential for bone formation and bone tissue engineering [3].

In this study, we demonstrated that BMP9 upregulated the expression of Notch receptors and ligands. Activation of Notch signaling remarkably enhanced BMP9-induced osteogenic differentiation both in vitro and in vivo. Furthermore, using the biodegradable citrate-based thermoresponsive PPCNg scaffold [42, 43, 49] leads to the formation of more mature bone with extensive angiogenesis and vascularization when the MSCs are stimulated by BMP9 and Notch. BMP9 and Notch were shown to up-regulate the expression of the angiogenic regulators in iMAD cells and ectopic bone tissues (Fig. 8). Therefore, our results demonstrate 


\section{Cellular Physiology Cell Physiol Biochem 2017;41:1905-1923 \begin{tabular}{c|l|l} 
DOI: 10.1159/000471945 & () 2017 The Author(s). Published by S. Karger AG, Basel
\end{tabular}

Fig. 8. A working model for osteogenesis-angiogenesis coupling in mesenchymal stem cells (MSCs) regulated by BMP9 and Notch signaling crosstalk. BMP9 induces osteogenic differentiation of MSCs by regulating important downstream targets, including Notch receptors and ligands. The activation of Notch signaling, which can be initiated by NICD or blocked by dnNotch, leads to up-regulating angiogenic signaling and neovascularization in newly formed bone. The presence of 3-D scaffold environment further facilitates the osteogenesis-angiogenesis coupling process induced by BMP9 and Notch signaling in MSCs.

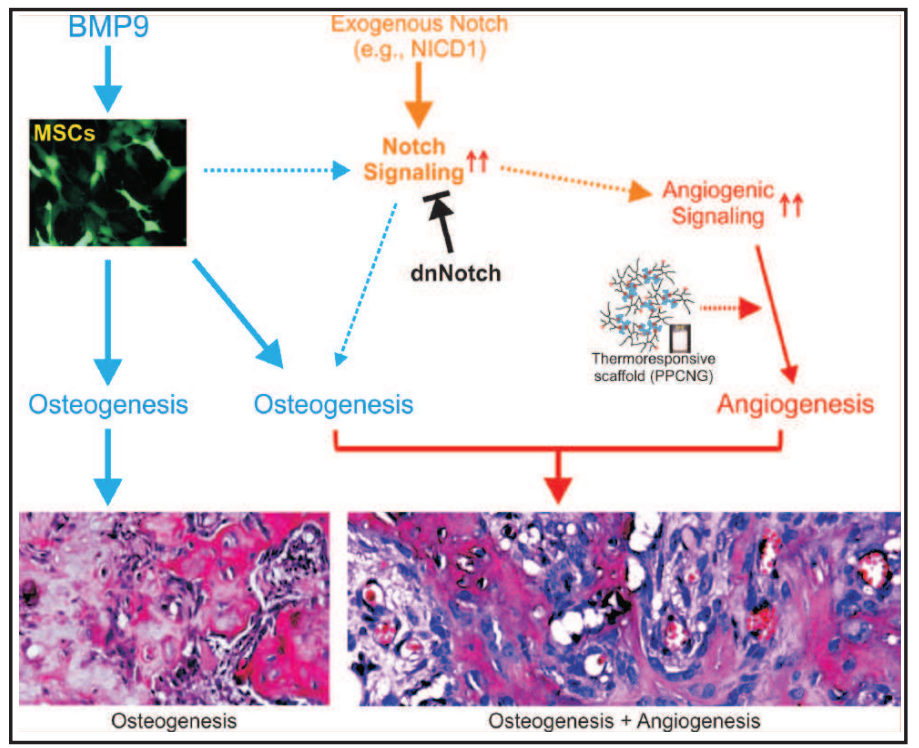

that simultaneous activation of the BMP9 and Notch signaling pathways efficiently couples osteogenesis and angiogenesis of MSCs in 3D scaffold environment (Fig. 8). Nonetheless, it should be pointed out that the in vivo osteogenic activity initiated by BMP9 and Notch crosstalk was carried out in immune-comprised athymic mice. It would be more interesting to determine whether such enhanced osteoangiogenic activity can be reproduced in immune competent animal models.

Notch signaling has been shown to be involved in bone and skeletal development [74, 75]. Abnormal expression of Notch signaling is associated with cancers and certain skeletal diseases $[16,76,77]$. While endothelial Notch activity was reported as an essential source for the coordinated osteogenesis and angiogenesis during the bone development [44], it is not clear if it's necessary to include endothelial progenitors in engineered bone tissues to achieve Notch-induced angiogenesis. It was reported that the expression of Notch ligand Jagged1 was able to induce osteogenesis [78], whereas the genetic deletion of Jagged1 resulted in defects in osteoblast development and differentiation during maxillary ossification [79]. We previously found that the downstream target gene of Notch signaling Hey1 was upregulated by BMP9 [28], suggesting BMP9 may act upstream of Notch signaling. It is noteworthy that unlike BMP9 an activation of Notch signaling (e.g., by overexpressing either NICD or Notch ligands) fails to induce de novo osteogenic differentiation and ectopic bone formation from MSCs as we demonstrated in this study that overexpressing NICD1 alone did not lead to osteogenic differentiation from the iMADs. We obtained similar results using different MSCs and/or overexpressing Dll1 or Jag1 (data not shown). Nonetheless, our results indicate that activating Notch signaling may be highly beneficial for the efficient coupling of osteogenesis and angiogenesis for bone tissue engineering. It is noteworthy that both BMP9 and Notch are reportedly to promote tumor growth, especially for bone tumors $[48,80]$, the combined use of BMP9 and Notch activators may be risky for certain bone defect repair procedures, such as osteosarcoma postoperative reconstruction.

MSCs are multipotent progenitor cells that can differentiate into multiple lineages including osteogenic, chondrogenic, and adipogenic lineages [81-84]. MSCs can be isolated from numerous tissues, and one of the major sources in adults is the bone marrow stromal cells [23, 83-87]. Among the various types of MSCs, adipose-derived mesenchymal stem cells (AD-MSCs) are considered more easily and repeatable harvested using minimally invasive techniques with low morbidity [88-90]. To facilitate more basic and translational studies on AD-MSCs, we have recently established reversibly immortalized AD-MSC iMAD cells, which exhibit the characteristics of multipotent MSCs and are highly responsive to BMP9-induced osteogenic differentiation [43]. Thus, the iMADs provide a valuable resource for developing novel and efficacious strategies for AD-MSC-based bone tissue engineering. 


\section{Cellular Physiology Cell Physiol Biochem 2017;41:1905-1923

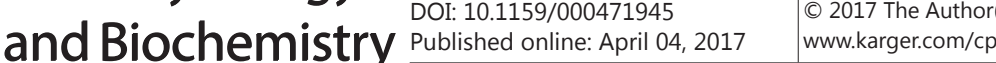 \\ Liao et al.: Coupled Osteoangiogenic Activity by BMP9 and Notch Crosstalk}

We recently demonstrated that thermoresponsive biomaterial PPCNg is a promising scaffold for stem cell-based bone engineering $[42,43]$. The PPCNg is gelatin-containing polyethylene glycolcitrate-co-N-isopropylacrylamide (PPCN) polymer which is biodegradable, biocompatible and intrinsically antioxidant [49]. One of the most prominent features of PPCNg is its hierarchical architecture of micropores and nanofibers with a lower critical solution temperature of $26^{\circ} \mathrm{C}$ and no significant volume reduction upon gelation [49]. We showed that PPCNg can gel robustly at $30^{\circ} \mathrm{C}$ at a final concentration as low as $50 \mathrm{mg} / \mathrm{ml}[42,43]$. Our in vivo studies showed that a significant biodegradation of PPCNg started approximately 3 weeks after subcutaneous injection, while a complete resorption of PPCN gel occurred at 4-5 weeks after injection $[42,43]$. Thus, PPCNg can be an ideal scaffold with the advantage of injectable substrate, easy for cell adhesion, absorbable with low immunogenicity, and providing a structural support for the cells with a platform for growth factor. In this study, we found that, compared with cells only group, the PPCNg group showed a high degree of osteogenesis-angiogenesis coupling during ectopic bone formation.

In summary, using the adipose-derived MSC iMADs cells, we demonstrated that BMP9 upregulated the expression of Notch receptors and ligands at the intermediate stage of osteogenic differentiation. The constitutively active form of Notch1 NICD1 remarkably enhanced BMP9-induced osteogenic differentiation both in vitro and in vivo, which was blunted by a dominant-negative form of Notch1 dnNotch1. The use of biodegradable PPCNg scaffold led to the formation of more mature bone with extensive angiogenesis and vascularization when the MSCs were stimulated by BMP9 and NICD1. BMP9 and NICD1 up-regulated the expression of angiogenic regulators in iMAD cells and Vegfa in ectopic bone tissues, which was effectively blocked by dnNotch1. Collectively, these results suggest that Notch signaling may play an important role in BMP9-induced osteogenesis and neovascularization. Thus, a simultaneous activation of BMP9 and Notch signaling pathways should efficiently couple osteogenesis and angiogenesis of MSCs in 3-D scaffold environment for successful bone tissue engineering.

\section{Acknowledgments}

The reported work was supported in part by research grants from the National Institutes of Health (AT004418, DE020140 to TCH and RRR), the US Department of Defense (OR130096 to JMW), the Scoliosis Research Society (TCH and MJL), the 973 Program of the Ministry of Science and Technology (MOST) of China (\# 2011CB707906 to TCH), the National Natural Science Foundation of China (\#81371972 and \#81572142 to WH), and the Science and Technology Research Project of Chongqing Municipal Education Commission of China (KJ1500217 to JC). Junyi Liao was a recipient of the Predoctoral Fellowship from the China Scholarship Council, the Graduate Research and Innovation Project from Chongqing Education Commission and the Outstanding Predoctorate Research Fellowship from Chongqing Medical University (\#CYB15098). This project was also supported in part by The University of Chicago Cancer Center Support Grant (P30CA014599) and the National Center for Advancing Translational Sciences of the National Institutes of Health through Grant Number UL1 TR000430. Funding sources were not involved in the study design; in the collection, analysis and interpretation of data; in the writing of the report; and in the decision to submit the paper for publication.

\section{Disclosure Statement}

The authors declare no conflict of interest.

\section{References}

-1 Luo J, Sun MH, Kang Q Peng Y, Jiang W, Luu HH, Luo Q, Park JY, Li Y, Haydon RC, He TC: Gene therapy for bone regeneration. Curr Gene Ther 2005;5:167-179. 


\section{Cellular Physiology Cell Physiol Biochem 2017;41:1905-1923 \begin{tabular}{c|l|l} 
DOI: 10.1159/000471945 & () 2017 The Author(s). Published by S. Karger AG, Basel
\end{tabular}

Liao et al.: Coupled Osteoangiogenic Activity by BMP9 and Notch Crosstalk

2 Almubarak S, Nethercott H, Freeberg M, Beaudon C, Jha A, Jackson W, Marcucio R, Miclau T, Healy K, Bahney C: Tissue engineering strategies for promoting vascularized bone regeneration. Bone 2016;83:197-209. Tatara AM, Mikos AG: Tissue Engineering in Orthopaedics. J Bone Joint Surg Am 2016;98:1132-1139. Bara JJ, Herrmann M, Evans CH, Miclau T, Ratcliffe A, Richards RG: Improving translation success of cellbased therapies in orthopaedics. J Orthop Res 2016;34:17-21.

5 Hankenson KD, Gagne K, Shaughnessy M: Extracellular signaling molecules to promote fracture healing and bone regeneration. Adv Drug Deliv Rev 2015;94:3-12.

6 Raisin S, Belamie E, Morille M: Non-viral gene activated matrices for mesenchymal stem cells based tissue engineering of bone and cartilage. Biomaterials 2016;104:223-237.

7 Raucci A, Bellosta P, Grassi R, Basilico C, Mansukhani A: Osteoblast proliferation or differentiation is regulated by relative strengths of opposing signaling pathways. J Cell Physiol 2008;215:442-451.

-8 Deng ZL, Sharff KA, Tang N, Song WX, Luo J, Luo X, Chen J, Bennett E, Reid R, Manning D, Xue A, Montag AG, Luu HH, Haydon RC, He TC: Regulation of osteogenic differentiation during skeletal development. Front Biosci 2008;13:2001-2021.

-9 Kim JH, Liu X, Wang J, Chen X, Zhang H, Kim SH, Cui J, Li R, Zhang W, Kong Y, Zhang J, Shui W, Lamplot J, Rogers MR, Zhao C, Wang N, Rajan P, Tomal J, Statz J, Wu N, Luu HH, Haydon RC, He TC: Wnt signaling in bone formation and its therapeutic potential for bone diseases. Ther Adv Musculoskelet Dis 2013;5:13-31.

10 Yang K, Wang X, Zhang H, Wang Z, Nan G, Li Y, Zhang F, Mohammed MK, Haydon RC, Luu HH, Bi Y, He TC: The evolving roles of canonical WNT signaling in stem cells and tumorigenesis: implications in targeted cancer therapies. Lab Invest 2016;96:116-136.

11 Denduluri SK, Olumuyiwa Idowu O, Wang Z, Liao Z, Yan Z, Mohammed MK, Ye J, Wei Q, Wang J, Zhao L, Luu HH: Insulin-like growth factor (IGF) signaling in tumorigenesis and the development of cancer drug resistance. Genes Dis 2015;2:13-25.

$\checkmark 12$ Teven CM, Farina EM, Rivas J, Reid RR: Fibroblast growth factor (FGF) signaling in development and skeletal diseases. Genes Dis 2014;1:199-213.

13 Jo A, Denduluri SK, Zhang B, Wang Z, Yin L, Yan Z, Kang R, Shi LL, Mok J, Lee MJ, Haydon RC: The Versatile Functions of Sox9 in Development, Stem Cells, and Human Diseases. Genes Dis 2014;1:149-161.

14 Louvi A, Artavanis-Tsakonas S: Notch and disease: a growing field. Semin Cell Dev Biol 2012;23:473-480.

15 Zanotti S, Canalis E: Notch and the skeleton. Mol Cell Biol 2010;30:886-896.

16 Guruharsha KG, Kankel MW, Artavanis-Tsakonas S: The Notch signalling system: recent insights into the complexity of a conserved pathway. Nat Rev Genet 2012;13:654-666.

17 Varga AC, Wrana JL: The disparate role of BMP in stem cell biology. Oncogene 2005;24:5713-5721.

18 Luu HH, Song WX, Luo X, Manning D, Luo J, Deng ZL, Sharff KA, Montag AG, Haydon RC, He TC: Distinct roles of bone morphogenetic proteins in osteogenic differentiation of mesenchymal stem cells. J Orthop Res 2007;25:665-677.

19 Wang RN, Green J, Wang Z, Deng Y, Qiao M, Peabody M, Zhang Q Ye J, Yan Z, Denduluri S, Idowu O, Li M, Shen C, Hu A, Haydon RC, Kang R, Mok J, Lee MJ, Luu HL, Shi LL: Bone Morphogenetic Protein (BMP) signaling in development and human diseases. Genes Dis 2014;1:87-105.

20 Cheng H, Jiang W, Phillips FM, Haydon RC, Peng Y, Zhou L, Luu HH, An N, Breyer B, Vanichakarn P, Szatkowski JP, Park JY, He TC: Osteogenic activity of the fourteen types of human bone morphogenetic proteins (BMPs). J Bone Joint Surg Am 2003;85-A:1544-1552.

-21 Kang Q, Sun MH, Cheng H, Peng Y, Montag AG, Deyrup AT, Jiang W, Luu HH, Luo J, Szatkowski JP, Vanichakarn P, Park JY, Li Y, Haydon RC, He TC: Characterization of the distinct orthotopic bone-forming activity of 14 BMPs using recombinant adenovirus-mediated gene delivery. Gene Ther 2004;11:1312-1320.

22 Luther G, Wagner ER, Zhu G, Kang Q, Luo Q, Lamplot J, Bi Y, Luo X, Luo J, Teven C, Shi Q Kim SH, Gao JL, Huang E, Yang K, Rames R, Liu X, Li M, Hu N, Liu H, Su Y, Chen L, He BC, Zuo GW, Deng ZL, Reid RR, Luu HH, Haydon RC, He TC: BMP-9 Induced Osteogenic Differentiation of Mesenchymal Stem Cells: Molecular Mechanism and Therapeutic Potential. Curr Gene Ther 2011;11:229-240.

-23 Lamplot JD, Qin J, Nan G, Wang J, Liu X, Yin L, Tomal J, Li R, Shui W, Zhang H, Kim SH, Zhang W, Zhang J, Kong Y, Denduluri S, Rogers MR, Pratt A, Haydon RC, Luu HH, Angeles J, Shi LL, He TC: BMP9 signaling in stem cell differentiation and osteogenesis. Am J Stem Cells 2013;2:1-21.

24 Wang Y, Hong S, Li M, Zhang J, Bi Y, He Y, Liu X, Nan G, Su Y, Zhu G, Li R, Zhang W, Wang J, Zhang H, Kong Y, Shui W, Wu N, He Y, Chen X, Luu HH, Haydon RC, Shi LL, He TC, Qin J: Noggin resistance contributes to the potent osteogenic capability of BMP9 in mesenchymal stem cells. J Orthop Res 2013;31:1796-1803. 


\section{Cellular Physiology Cell Physiol Biochem 2017;41:1905-1923 and Biochemistry Published online: April 04, $2017 \quad \begin{aligned} & \text { D 2017 The Authors. } \\ & \text { www.karger.com/cpb }\end{aligned}$}

Liao et al.: Coupled Osteoangiogenic Activity by BMP9 and Notch Crosstalk

25 Peng Y, Kang Q Cheng H, Li X, Sun MH, Jiang W, Luu HH, Park JY, Haydon RC, He TC: Transcriptional characterization of bone morphogenetic proteins (BMPs)-mediated osteogenic signaling. J Cell Biochem 2003;90:1149-1165.

-26 Peng Y, Kang Q Luo Q, Jiang W, Si W, Liu BA, Luu HH, Park JK, Li X, Luo J, Montag AG, Haydon RC, He TC: Inhibitor of DNA binding/differentiation helix-loop-helix proteins mediate bone morphogenetic proteininduced osteoblast differentiation of mesenchymal stem cells. J Biol Chem 2004;279:32941-32949.

27 Luo Q, Kang Q, Si W, Jiang W, Park JK, Peng Y, Li X, Luu HH, Luo J, Montag AG, Haydon RC, He TC: Connective Tissue Growth Factor (CTGF) Is Regulated by Wnt and Bone Morphogenetic Proteins Signaling in Osteoblast Differentiation of Mesenchymal Stem Cells. J Biol Chem 2004;279:55958-55968.

28 Sharff KA, Song WX, Luo X, Tang N, Luo J, Chen J, Bi Y, He BC, Huang J, Li X, Jiang W, Zhu GH, Su Y, He Y, Shen J, Wang Y, Chen L, Zuo GW, Liu B, Pan X, Reid RR, Luu HH, Haydon RC, He TC: Hey1 Basic Helix-Loop-Helix Protein Plays an Important Role in Mediating BMP9-induced Osteogenic Differentiation of Mesenchymal Progenitor Cells. J Biol Chem 2009;284:649-659.

-29 Huang E, Zhu G, Jiang W, Yang K, Gao Y, Luo Q, Gao JL, Kim SH, Liu X, Li M, Shi Q, Hu N, Wang L, Liu H, Cui J, Zhang W, Li R, Chen X, Kong YH, Zhang J, Wang J, Shen J, Bi Y, Statz J, He BC, Luo J, Wang H, Xiong F, Luu HH, Haydon RC, Yang L, He TC: Growth hormone synergizes with BMP9 in osteogenic differentiation by activating the JAK/STAT/IGF1 pathway in murine multilineage cells. J Bone Miner Res 2012;27:1566-1575.

-30 Tang N, Song WX, Luo J, Luo X, Chen J, Sharff KA, Bi Y, He BC, Huang JY, Zhu GH, Su YX, Jiang W, Tang M, He Y, Wang Y, Chen L, Zuo GW, Shen J, Pan X, Reid RR, Luu HH, Haydon RC, He TC: BMP9-induced osteogenic differentiation of mesenchymal progenitors requires functional canonical Wnt/beta-catenin signaling. J Cell Mol Med 2009;13:2448-2464.

-31 Chen L, Jiang W, Huang J, He BC, Zuo GW, Zhang W, Luo Q Shi Q, Zhang BQ Wagner ER, Luo J, Tang M, Wietholt C, Luo X, Bi Y, Su Y, Liu B, Kim SH, He CJ, Hu Y, Shen J, Rastegar F, Huang E, Gao Y, Gao JL, Zhou JZ, Reid RR, Luu HH, Haydon RC, He TC, Deng ZL: Insulin-like growth factor 2 (IGF-2) potentiates BMP-9induced osteogenic differentiation and bone formation. J Bone Miner Res 2010;25:2447-2459.

32 Zhang W, Deng ZL, Chen L, Zuo GW, Luo Q, Shi Q Zhang BQ, Wagner ER, Rastegar F, Kim SH, Jiang W, Shen J, Huang E, Gao Y, Gao JL, Zhou JZ, Luo J, Huang J, Luo X, Bi Y, Su Y, Yang K, Liu H, Luu HH, Haydon RC, He TC, He BC: Retinoic acids potentiate BMP9-induced osteogenic differentiation of mesenchymal progenitor cells. PLoS One 2010;5:e11917.

-33 Hu N, Jiang D, Huang E, Liu X, Li R, Liang X, Kim SH, Chen X, Gao JL, Zhang H, Zhang W, Kong YH, Zhang J, Wang J, Shui W, Luo X, Liu B, Cui J, Rogers MR, Shen J, Zhao C, Wang N, Wu N, Luu HH, Haydon RC, He TC, Huang W: BMP9-regulated angiogenic signaling plays an important role in the osteogenic differentiation of mesenchymal progenitor cells. J Cell Sci 2013;126:532-541.

-34 Liu X, Qin J, Luo Q, Bi Y, Zhu G, Jiang W, Kim SH, Li M, Su Y, Nan G, Cui J, Zhang W, Li R, Chen X, Kong Y, Zhang J, Wang J, Rogers MR, Zhang H, Shui W, Zhao C, Wang N, Liang X, Wu N, He Y, Luu HH, Haydon RC, Shi LL, Li T, He TC, Li M: Cross-talk between EGF and BMP9 signalling pathways regulates the osteogenic differentiation of mesenchymal stem cells. J Cell Mol Med 2013;17:1160-1172.

-35 Zhang H, Wang J, Deng F, Huang E, Yan Z, Wang Z, Deng Y, Zhang Q, Zhang Z, Ye J, Qiao M, Li R, Wang J, Wei Q Zhou G, Luu HH, Haydon RC, He TC, Deng F: Canonical Wnt signaling acts synergistically on BMP9induced osteo/odontoblastic differentiation of stem cells of dental apical papilla (SCAPs). Biomaterials 2015;39:145-154.

-36 Greenhill C: Bone. Formation of blood vessels in bone maturation and regeneration. Nat Rev Endocrinol 2014;10:250.

37 Kusumbe AP, Ramasamy SK, Adams RH: Coupling of angiogenesis and osteogenesis by a specific vessel subtype in bone. Nature 2014;507:323-328.

-38 Maes C, Clemens TL: Angiogenic-osteogenic coupling: the endothelial perspective. Bonekey Rep 2014;3:578.

39 Barabaschi GD, Manoharan V, Li Q, Bertassoni LE: Engineering Pre-vascularized Scaffolds for Bone Regeneration. Adv Exp Med Biol 2015;881:79-94.

40 Zhou N, Hu N, Liao JY, Lin LB, Zhao C, Si WK, Yang Z, Yi SX, Fan TX, Bao W, Liang X, Wei X, Chen H, Chen C, Chen Q, Lin X, Huang W: HIF-1alpha as a Regulator of BMP2-Induced Chondrogenic Differentiation, Osteogenic Differentiation, and Endochondral Ossification in Stem Cells. Cell Physiol Biochem 2015;36:44-60. 


\section{Cellular Physiology Cell Physiol Biochem 2017;41:1905-1923 \begin{tabular}{ll|l} 
and: 10.1159/000471945 & $\begin{array}{l}\text { () } 2017 \text { The Author(s). Published by S. Karger AG, Basel } \\
\text { www.karger.com/cpb }\end{array}$ \\
\hline
\end{tabular}}

Liao et al.: Coupled Osteoangiogenic Activity by BMP9 and Notch Crosstalk

41 Shui W, Zhang W, Yin L, Nan G, Liao Z, Zhang H, Wang N, Wu N, Chen X, Wen S, He Y, Deng F, Zhang J, Luu HH, Shi LL, Hu Z, Haydon RC, Mok JM, He TC: Characterization of scaffold carriers for BMP9-transduced osteoblastic progenitor cells in bone regeneration. J Biomed Mater Res A 2014;102:3429-3438.

42 Ye J, Wang J, Zhu Y, Wei Q Wang X, Yang J, Tang S, Liu H, Fan J, Zhang F, Farina EM, Mohammed MK, Zou Y, Song D, Liao J, Huang J, Guo D, Lu M, Liu F, Liu J, Li L, Ma C, Hu X, Haydon RC, Lee MJ, Reid RR, Ameer GA, Yang L, He TC: A thermoresponsive polydiolcitrate-gelatin scaffold and delivery system mediates effective bone formation from BMP9-transduced mesenchymal stem cells. Biomed Mater 2016;11:025021.

-43 Lu S, Wang J, Ye J, Zou Y, Zhu Y, Wei Q, Wang X, Tang S, Liu H, Fan J, Zhang F, Farina EM, Mohammed MM, Song D, Liao J, Huang J, Guo D, Lu M, Liu F, Liu J, Li L, Ma C, Hu X, Lee MJ, Reid RR, Ameer GA, Zhou D, He T: Bone morphogenetic protein 9 (BMP9) induces effective bone formation from reversibly immortalized multipotent adipose-derived (iMAD) mesenchymal stem cells. Am J Transl Res 2016;8:3710-3730.

44 Ramasamy SK, Kusumbe AP, Wang L, Adams RH: Endothelial Notch activity promotes angiogenesis and osteogenesis in bone. Nature 2014;507:376-380.

45 Yavropoulou MP, Yovos JG: The role of Notch signaling in bone development and disease. Hormones (Athens) 2014;13:24-37.

46 Zanotti S, Canalis E: Notch Signaling and the Skeleton. Endocr Rev 2016;37:223-253.

47 Bray SJ: Notch signalling: a simple pathway becomes complex. Nat Rev Mol Cell Biol 2006;7:678-689.

48 Li R, Zhang W, Cui J, Shui W, Yin L, Wang Y, Zhang H, Wang N, Wu N, Nan G, Chen X, Wen S, Deng F, Zhou G, Liao Z, Zhang J, Zhang Q Yan Z, Liu W, Zhang Z, Ye J, Deng Y, Luu HH, Haydon RC, He TC, Deng ZL: Targeting BMP9-promoted human osteosarcoma growth by inactivation of notch signaling. Curr Cancer Drug Targets 2014;14:274-285.

49 Yang J, van Lith R, Baler K, Hoshi RA, Ameer GA: A thermoresponsive biodegradable polymer with intrinsic antioxidant properties. Biomacromolecules 2014;15:3942-3952.

50 Wu N, Zhang H, Deng F, Li R, Zhang W, Chen X, Wen S, Wang N, Zhang J, Yin L, Liao Z, Zhang Z, Zhang Q, Yan Z, Liu W, Wu D, Ye J, Deng Y, Yang K, Luu HH, Haydon RC, He TC: Overexpression of Ad5 precursor terminal protein accelerates recombinant adenovirus packaging and amplification in HEK-293 packaging cells. Gene Ther 2014;21:629-637.

-51 Chen X, Cui J, Yan Z, Zhang H, Chen X, Wang N, Shah P, Deng F, Zhao C, Geng N, Li M, Denduluri SK, Haydon RC, Luu HH, Reid RR, He TC: Sustained high level transgene expression in mammalian cells mediated by the optimized piggyBac transposon system. Genes Dis 2015;2:96-105.

-52 Deng Y, Wang Z, Zhang F, Qiao M, Yan Z, Wei Q Wang J, Liu H, Fan J, Zou Y, Liao J, Hu X, Chen L, Yu X, Haydon RC, Luu HH, Qi H, He TC, Zhang J: A Blockade of IGF Signaling Sensitizes Human Ovarian Cancer Cells to the Anthelmintic Niclosamide-Induced Anti-Proliferative and Anticancer Activities. Cell Physiol Biochem 2016;39:871-888.

53 Liao Z, Nan G, Yan Z, Zeng L, Deng Y, Ye J, Zhang Z, Qiao M, Li R, Denduluri S, Wang J, Wei Q, Geng N, Zhao L, Lu S, Wang X, Zhou G, Luu HH, Haydon RC, He TC, Wang Z: The Anthelmintic Drug Niclosamide Inhibits the Proliferative Activity of Human Osteosarcoma Cells by Targeting Multiple Signal Pathways. Curr Cancer Drug Targets 2015;15:726-738.

-54 He TC, Zhou S, da Costa LT, Yu J, Kinzler KW, Vogelstein B: A simplified system for generating recombinant adenoviruses. Proc Natl Acad Sci U S A 1998;95:2509-2514.

-55 Luo J, Deng ZL, Luo X, Tang N, Song WX, Chen J, Sharff KA, Luu HH, Haydon RC, Kinzler KW, Vogelstein B, He TC: A protocol for rapid generation of recombinant adenoviruses using the AdEasy system. Nat Protoc 2007;2:1236-1247.

-56 Kang Q, Song WX, Luo Q, Tang N, Luo J, Luo X, Chen J, Bi Y, He BC, Park JK, Jiang W, Tang Y, Huang J, Su Y, Zhu GH, He Y, Yin H, Hu Z, Wang Y, Chen L, Zuo GW, Pan X, Shen J, Vokes T, Reid RR, Haydon RC, Luu HH, He TC: A comprehensive analysis of the dual roles of BMPs in regulating adipogenic and osteogenic differentiation of mesenchymal progenitor cells. Stem Cells Dev 2009;18:545-559.

-57 Li R, Yan Z, Ye J, Huang H, Wang Z, Wei Q, Wang J, Zhao L, Lu S, Wang X, Tang S, Fan J, Zhang F, Zou Y, Song D, Liao J, Lu M, Liu F, Shi LL, Athiviraham A, Lee MJ, He TC, Zhang Z: The Prodomain-Containing BMP9 Produced from a Stable Line Effectively Regulates the Differentiation of Mesenchymal Stem Cells. Int J Med Sci 2016;13:8-18. 


\section{Cellular Physiology Cell Physiol Biochem 2017;41:1905-1923 \begin{tabular}{c|l} 
DOI: 10.1159/000471945 & (c) 2017 The Author(s). Published by S. Karger AG, Basel
\end{tabular}

Liao et al.: Coupled Osteoangiogenic Activity by BMP9 and Notch Crosstalk

58 Huang E, Bi Y, Jiang W, Luo X, Yang K, Gao JL, Gao Y, Luo Q, Shi Q, Kim SH, Liu X, Li M, Hu N, Liu H, Cui J, Zhang W, Li R, Chen X, Shen J, Kong Y, Zhang J, Wang J, Luo J, He BC, Wang H, Reid RR, Luu HH, Haydon RC, Yang L, He TC: Conditionally Immortalized Mouse Embryonic Fibroblasts Retain Proliferative Activity without Compromising Multipotent Differentiation Potential. PLoS One 2012;7:e32428.

-59 Zhao C, Wu N, Deng F, Zhang H, Wang N, Zhang W, Chen X, Wen S, Zhang J, Yin L, Liao Z, Zhang Z, Zhang Q Yan Z, Liu W, Wu D, Ye J, Deng Y, Zhou G, Luu HH, Haydon RC, Si W, He TC: Adenovirus-mediated gene transfer in mesenchymal stem cells can be significantly enhanced by the cationic polymer polybrene. PLoS One 2014;9:e92908.

60 Untergasser A, Cutcutache I, Koressaar T, Ye J, Faircloth BC, Remm M, Rozen SG: Primer3--new capabilities and interfaces. Nucleic Acids Res 2012;40:e115.

61 Zhang Q, Wang J, Deng F, Yan Z, Xia Y, Wang Z, Ye J, Deng Y, Zhang Z, Qiao M, Li R, Denduluri SK, Wei Q, Zhao L, Lu S, Wang X, Tang S, Liu H, Luu HH, Haydon RC, He TC, Jiang L: TqPCR: A Touchdown qPCR Assay with Significantly Improved Detection Sensitivity and Amplification Efficiency of SYBR Green qPCR. PLoS One 2015;10:e0132666.

62 Lamplot JD, Liu B, Yin L, Zhang W, Wang Z, Luther G, Wagner E, Li R, Nan G, Shui W, Yan Z, Rames R, Deng F, Zhang H, Liao Z, Liu W, Zhang J, Zhang Z, Zhang Q Ye J, Deng Y, Qiao M, Haydon RC, Luu HH, Angeles J, Shi LL, He TC, Ho SH: Reversibly Immortalized Mouse Articular Chondrocytes Acquire Long-Term Proliferative Capability while Retaining Chondrogenic Phenotype. Cell Transplant 2015;24:1053-1066.

63 Gao Y, Huang E, Zhang H, Wang J, Wu N, Chen X, Wang N, Wen S, Nan G, Deng F, Liao Z, Wu D, Zhang B, Zhang J, Haydon RC, Luu HH, Shi LL, He TC: Crosstalk between Wnt/beta-Catenin and Estrogen Receptor Signaling Synergistically Promotes Osteogenic Differentiation of Mesenchymal Progenitor Cells. PLoS One 2013;8:e82436.

64 Wang N, Zhang W, Cui J, Zhang H, Chen X, Li R, Wu N, Chen X, Wen S, Zhang J, Yin L, Deng F, Liao Z, Zhang Z, Zhang Q, Yan Z, Liu W, Ye J, Deng Y, Wang Z, Qiao M, Luu HH, Haydon RC, Shi LL, Liang H, He TC: The piggyBac Transposon-Mediated Expression of SV40 T Antigen Efficiently Immortalizes Mouse Embryonic Fibroblasts (MEFs). PLoS One 2014;9:e97316.

-65 Deng F, Chen X, Liao Z, Yan Z, Wang Z, Deng Y, Zhang Q Zhang Z, Ye J, Qiao M, Li R, Denduluri S, Wang J, Wei Q, Li M, Geng N, Zhao L, Zhou G, Zhang P, Luu HH, Haydon RC, Reid RR, Yang T, He TC: A Simplified and Versatile System for the Simultaneous Expression of Multiple siRNAs in Mammalian Cells Using Gibson DNA Assembly. PLoS One 2014;9:e113064.

-66 Li Y, Wagner ER, Yan Z, Wang Z, Luther G, Jiang W, Ye J, Wei Q Wang J, Zhao L, Lu S, Wang X, Mohammed MK, Tang S, Liu H, Fan J, Zhang F, Zou Y, Song D, Liao J, Haydon RC, Luu HH, He TC: The Calcium-Binding Protein S100A6 Accelerates Human Osteosarcoma Growth by Promoting Cell Proliferation and Inhibiting Osteogenic Differentiation. Cell Physiol Biochem 2015;37:2375-2392.

67 Luo J, Tang M, Huang J, He BC, Gao JL, Chen L, Zuo GW, Zhang W, Luo Q, Shi Q, Zhang BQ, Bi Y, Luo X, Jiang W, Su Y, Shen J, Kim SH, Huang E, Gao Y, Zhou JZ, Yang K, Luu HH, Pan X, Haydon RC, Deng ZL, He TC: TGFbeta/ BMP type I receptors ALK1 and ALK2 are essential for BMP9-induced osteogenic signaling in mesenchymal stem cells. J Biol Chem 2010;285:29588-29598.

68 Su Y, Wagner ER, Luo Q, Huang J, Chen L, He BC, Zuo GW, Shi Q Zhang BQ, Zhu G, Bi Y, Luo J, Luo X, Kim SH, Shen J, Rastegar F, Huang E, Gao Y, Gao JL, Yang K, Wietholt C, Li M, Qin J, Haydon RC, He TC, Luu $\mathrm{HH}$ : Insulin-like growth factor binding protein 5 suppresses tumor growth and metastasis of human osteosarcoma. Oncogene 2011;30:3907-3917.

-69 Wang J, Zhang H, Zhang W, Huang E, Wang N, Wu N, Wen S, Chen X, Liao Z, Deng F, Yin L, Zhang J, Zhang Q Yan Z, Liu W, Zhang Z, Ye J, Deng Y, Luu HH, Haydon RC, He TC, Deng F: Bone Morphogenetic Protein-9 (BMP9) Effectively Induces Osteo/Odontoblastic Differentiation of the Reversibly Immortalized Stem Cells of Dental Apical Papilla. Stem Cells Dev 2014;23:1405-1416.

-70 Yan Z, Yin L, Wang Z, Ye J, Zhang Z, Li R, Denduluri SK, Wang J, Wei Q, Zhao L, Lu S, Wang X, Tang S, Shi LL, Lee MJ, He TC, Deng ZL: A Novel Organ Culture Model of Mouse Intervertebral Disc Tissues. Cells Tissues Organs 2016;201:38-50.

-71 Haydon RC, Deyrup A, Ishikawa A, Heck R, Jiang W, Zhou L, Feng T, King D, Cheng H, Breyer B, Peabody T, Simon MA, Montag AG, He TC: Cytoplasmic and/or nuclear accumulation of the beta-catenin protein is a frequent event in human osteosarcoma. Int J Cancer 2002;102:338-342. 


\section{Cellular Physiology Cell Physiol Biochem 2017;41:1905-1923 and Biochemistry DOI: 10.1159/000471945 1 () 2017 The Author(s). Published by S. Karger AG, Basel

Liao et al.: Coupled Osteoangiogenic Activity by BMP9 and Notch Crosstalk

-72 Chen X, Luther G, Zhang W, Nan G, Wagner ER, Liao Z, Wu N, Zhang H, Wang N, Wen S, He Y, Deng F, Zhang J, Wu D, Zhang B, Haydon RC, Zhou L, Luu HH, He TC: The E-F Hand Calcium-Binding Protein S100A4 Regulates the Proliferation, Survival and Differentiation Potential of Human Osteosarcoma Cells. Cell Physiol Biochem 2013;32:1083-1096.

-73 He BC, Chen L, Zuo GW, Zhang W, Bi Y, Huang J, Wang Y, Jiang W, Luo Q, Shi Q Zhang BQ Liu B, Lei X, Luo J, Luo X, Wagner ER, Kim SH, He CJ, Hu Y, Shen J, Zhou Q Rastegar F, Deng ZL, Luu HH, He TC, Haydon RC: Synergistic antitumor effect of the activated PPARgamma and retinoid receptors on human osteosarcoma. Clin Cancer Res 2010;16:2235-2245.

74 Canalis E: Notch signaling in osteoblasts. Sci Signal 2008;1:pe17.

75 Engin F, Lee B: NOTCHing the bone: insights into multi-functionality. Bone 2010;46:274-280.

76 Bolos V, Grego-Bessa J, de la Pompa JL: Notch signaling in development and cancer. Endocr Rev 2007;28:339-363.

-77 Engin F, Bertin T, Ma O, Jiang MM, Wang L, Sutton RE, Donehower LA, Lee B: Notch signaling contributes to the pathogenesis of human osteosarcomas. Hum Mol Genet 2009;18:1464-1470.

78 Dishowitz MI, Zhu F, Sundararaghavan HG, Ifkovits JL, Burdick JA, Hankenson KD: Jagged1 immobilization to an osteoconductive polymer activates the Notch signaling pathway and induces osteogenesis. J Biomed Mater Res A 2014;102:1558-1567.

79 Hill CR, Yuasa M, Schoenecker J, Goudy SL: Jagged1 is essential for osteoblast development during maxillary ossification. Bone 2014;62:10-21.

80 Luo X, Chen J, Song WX, Tang N, Luo J, Deng ZL, Sharff KA, He G, Bi Y, He BC, Bennett E, Huang J, Kang Q, Jiang W, Su Y, Zhu GH, Yin H, He Y, Wang Y, Souris JS, Chen L, Zuo GW, Montag AG, Reid RR, Haydon RC, Luu HH, He TC: Osteogenic BMPs promote tumor growth of human osteosarcomas that harbor differentiation defects. Lab Invest 2008;88:1264-1277.

-81 Pittenger MF, Mackay AM, Beck SC, Jaiswal RK, Douglas R, Mosca JD, Moorman MA, Simonetti DW, Craig S, Marshak DR: Multilineage potential of adult human mesenchymal stem cells. Science 1999;284:143-147.

82 Caplan AI, Bruder SP: Mesenchymal stem cells: building blocks for molecular medicine in the 21st century. Trends Mol Med 2001;7:259-264.

83 Rastegar F, Shenaq D, Huang J, Zhang W, Zhang BQ, He BC, Chen L, Zuo GW, Luo Q, Shi Q Wagner ER, Huang E, Gao Y, Gao JL, Kim SH, Zhou JZ, Bi Y, Su Y, Zhu G, Luo J, Luo X, Qin J, Reid RR, Luu HH, Haydon RC, Deng ZL, He TC: Mesenchymal stem cells: Molecular characteristics and clinical applications. World J Stem Cells 2010;2:67-80.

84 Teven CM, Liu X, Hu N, Tang N, Kim SH, Huang E, Yang K, Li M, Gao JL, Liu H, Natale RB, Luther G, Luo Q, Wang L, Rames R, Bi Y, Luo J, Luu HH, Haydon RC, Reid RR, He TC: Epigenetic regulation of mesenchymal stem cells: a focus on osteogenic and adipogenic differentiation. Stem Cells Int 2011;2011:201371.

-85 Shenaq DS, Rastegar F, Petkovic D, Zhang BQ, He BC, Chen L, Zuo GW, Luo Q, Shi Q Wagner ER, Huang E, Gao Y, Gao JL, Kim SH, Yang K, Bi Y, Su Y, Zhu G, Luo J, Luo X, Qin J, Reid RR, Luu HH, Haydon RC, He TC: Mesenchymal Progenitor Cells and Their Orthopedic Applications: Forging a Path towards Clinical Trials. Stem Cells Int 2010;2010:519028.

-86 Alexander D, Biller R, Rieger M, Ardjomandi N, Reinert S: Phenotypic characterization of a human immortalized cranial periosteal cell line. Cell Physiol Biochem 2015;35:2244-2254.

-87 Morabito C, D'Alimonte I, Pierdomenico L, Pipino C, Guarnieri S, Caprara GA, Antonucci I, Ciccarelli R, Marchisio M, Pandolfi A, Mariggio MA: Calcitonin-induced effects on amniotic fluid-derived mesenchymal stem cells. Cell Physiol Biochem 2015;36:259-273.

88 Halvorsen YC, Wilkison WO, Gimble JM: Adipose-derived stromal cells--their utility and potential in bone formation. Int J Obes Relat Metab Disord 2000;24:S41-44.

-89 Zuk PA, Zhu M, Mizuno H, Huang J, Futrell JW, Katz AJ, Benhaim P, Lorenz HP, Hedrick MH: Multilineage cells from human adipose tissue: implications for cell- based therapies. Tissue Eng 2001;7:211-228.

90 Kapur SK, Dos-Anjos Vilaboa S, Llull R, Katz AJ: Adipose tissue and stem/progenitor cells: discovery and development. Clin Plast Surg 2015;42:155-167. 